\title{
Animal violence demystified
}

\author{
Deepa Natarajan ${ }^{1 *}$ and Doretta Caramaschi ${ }^{2}$ \\ 1 Department of Behavioral Physiology, Biological Center, University of Groningen, Haren, Netherlands \\ 2 Groupe de Recherche sur I'Inadaptation Psychosociale chez I'Enfant, Université de Montréal, Montréal, OC, Canada
}

\section{Edited by:}

Carmen Sandi, Ecole Polytechnique de Lausanne, Switzerland

\section{Reviewed by:}

Alexa H. Veenema, University of Massachusetts, USA

Carmen Sandi, Ecole Polytechnique de Lausanne, Switzerland

*Correspondence:

Deepa Natarajan, Department of Behavioral Physiology, University of Groningen, P.O. Box 14, 9750 AA,

Haren, Netherlands.

e-mail:d.natarajan@rug.n
Violence has been observed in humans and animals alike, indicating its evolutionary/biological significance. However, violence in animals has often been confounded with functional forms of aggressive behavior. Currently, violence in animals is identified primarily as either a quantitative behavior (an escalated, pathological and abnormal form of aggression characterized primarily by short attack latencies, and prolonged and frequent harm-oriented conflict behaviors) or a qualitative one (characterized by attack bites aimed at vulnerable parts of the opponent's body and context independent attacks regardless of the environment or the sex and type of the opponent). Identification of an operational definition for violence thus not only helps in understanding its potential differences from adaptive forms of aggression but also in the selection of appropriate animal models for both. We address this issue theoretically by drawing parallels from research on aggression and appeasement in humans and other animals. We also provide empirical evidences for violence in mice selected for high aggression by comparing our findings with other currently available potentially violent rodent models. The following violence-specific features namely (1) Display of low levels of pre-escalatory/ritualistic behaviors. (2) Immediate and escalated offense durations with low withdrawal rates despite the opponent's submissive supine and crouching/defeat postures. (3) Context independent indiscriminate attacks aimed at familiar/unfamiliar females, anaesthetized males and opponents and in neutral environments. (4) Orientation of attack-bites toward vulnerable body parts of the opponent resulting in severe wounding. (5) Low prefrontal serotonin (5-HT) levels upon repeated aggression. (6) Low basal heart rates and hyporesponsive hypothalamus-pituitary-adrenocortical (HPA) axis were identified uniquely in the short attack latency (SAL) mice suggesting a qualitative difference between violence and adaptive aggression in animals.

Keywords: violence, aggression, animal models, mice, SAL

\section{INTRODUCTION}

Violence is a global concern, with severe implications for health, capital and the economy (in)directly (Krug et al., 2002). The World Health Organization (WHO) has defined violence as 'the intentional use of physical force or power, threatened or actual, against oneself, another person, or against a group or community that either results in or has a high likelihood of injury, death, psychological harm, mal-development or deprivation' (Krug et al., 2002). Incidentally, violence is not restricted to human societies alone but has also been observed in a variety of other animal species, thus rendering animals a useful model for investigating violence. Research on violence in animals was first carried out in the last century using feral species, and has been commonly associated with crippling injury and/or death. This was originally investigated inter-specifically in predator-prey relationships (Southwick, 1970) but later was also observed under unusual environmental circumstances including captivity (Carpenter, 1934), crowding (Darling, 1937) or social disorganization of the population intraspecifically (Zuckerman, 1932; Carpenter, 1942; Calhoun, 1948; Southwick, 1955; Corbett, 1957; Carrington, 1958; Myers, 1966; Burns, 1968; Gilbert, 1968; Caras, 1969; Stokes, 1969). Violence has been documented from field studies in a number of vertebrate and invertebrate taxa, namely non-human primates, elephants, tigers, grizzly bears, lizards, social insects and rodents, suggesting a deep underlying evolutionary basis (Carpenter, 1934; Schaller, 1963; Lorenz, 1966; Southwick, 1970; Huntingford and Turner, 1987; Archer, 1988; Suomi, 2003; de Waal, 2005; Wrangham et al., 2006). Documentations of animal violence under (semi-)natural and controlled laboratory conditions have been carried out since then, primarily using different feline and rodent models. These studies have indicated additionally, a common biological underpinning for violence in humans and animals alike (described later).

Not withstanding the above, there has been a considerable awakening recently in the animal literature that violence may be confounded with naturally occurring, adaptive aggression. Here we provide several examples to clarify this controversy. We also propose a few key behavioral features that we believe would not only help in distinguishing violence from adaptive/functional aggression in animals, but also in offering 'face' validity to animal models of human violence. We describe several landmark manipulative studies on animals and address their strengths/weaknesses using our definitions. Further, the potentials and pitfalls of a particular mouse model, namely the SAL mouse, are assessed by comparison with other currently available rodent models and with human 'violence', using evidence from multiple disciplines. 


\section{VIOLENCE VERSUS AGGRESSION - OPERATIONAL DEFINITIONS}

Animal violence has been studied through several manipulations (described later) using the following behavioral measures: attack latencies; frequency, intensity and duration of attack bouts; and frequency of attack bites. Violence in animals has been described as an escalated, pathological and abnormal form of aggression characterized primarily by early attack latencies, prolonged and frequent consummate behaviors and attack bites (Miczek et al., 2003). These parameters thus seem largely quantitative, in that violence is expected merely to show earlier attack latencies and higher frequencies and durations of consummatory behavior than adaptive aggression. Measures of a qualitative nature have been developed independently, where violence is considered qualitatively different from adaptive aggression. Attack bites, for instance, aimed at vulnerable parts of the opponent's body are considered characteristic of abnormal aggression (Haller et al., 2005). A few additional qualitative facets have been studied, namely lack of ritualistic behaviors as measured by Attack/Threat (A/T) ratios (Haller et al., 2005) and context independent attacks (Koolhaas, 1978) aimed at the opponent regardless of its sex or state (free-living/anaesthetized/dead) or the environment (home/neutral cage). Violence can therefore in principle refer to an escalated (hyper-) aggression (quantitative) or to an abnormal form of aggression (qualitative), or even to aggression that is both escalated and abnormal (both), which is unsurprisingly rare (described later in this section). We provide a few evidences below to illustrate this ambiguity.

The first line of evidence for a possible difference between violence and aggression came from neurochemical studies in rodents. Van der Vegt et al. (2003) and de Boer et al. (2003) showed a positive correlation between 5-hydroxyindoleacetic acid (5-HIAA) levels and aggression in wild-type Groningen (WTG) rats, in contrast to human data where low 5-HIAA levels are associated with impulsivity and suicidal behaviors (Asberg et al., 1976; Brown et al., 1979). However, upon repeated/trained aggression, these highly aggressive rats showed a negative correlation between aggression and 5-HIAA levels, in line with the clinical data (de Boer and Koolhaas, 2005). The key difference is thus the shift in correlation from positive to negative, suggesting a possible experience-driven qualitative shift from adaptive aggression to violence. In line with the qualitative school of thought, de Boer et al. (2003) also showed absence of the highly aggressive phenotype in Wistar rats, a laboratory rodent model currently used for aggression research. These animals are considered docile by nature (Barnett and Smart, 1975; Ebert, 1976; Singleton and Hay, 1982). Although genetic information about laboratory rodent strains is abundant, use of docile strains lacking any appreciable aggression heavily questions their validity as models of human violence, in that the induced phenotype can be quantitatively more aggressive without necessarily being violent. This concern is heightened by the extensive use of these docile strains in several gene-knockout studies revealing possible single-gene effects on aggression and/or even violence (see Miczek et al., 2001 for review). Thus, the primary stumbling blocks in the understanding of violence have been the lack of operational definitions of violence and adaptive aggression in animals and the likely consequent use of inappropriate animal models.
In addition, in studies on humans, the term 'violence' is often used synonymously with 'aggression'. Violence/aggression in humans has been identified primarily as a behavioral anomaly of social communication. However, studies on animals suggest that aggression and violence may be distinct phenomena (Haller and Kruk, 2006), which underlines the importance of clearly defining these terms, as we described above. Violence or maladaptive/ pathological aggression in a simplistic sense has been defined as an exaggerated/escalated form of aggression leading to extreme harm in humans and animals alike. Aggression, on the other hand, has been defined primarily as a form of social communication, which is pro-inhibitory and aimed at functional endpoints such as the acquisition of food, shelter, mates and status (Scott, 1958; Koolhaas et al., 2010). Thus, there is inconsistency in the definition of these terms as applied to humans and animals.

This issue is highlighted by a brief survey of the scientific literature. A PubMed search with the keywords 'violence, humans' or 'violence, animals' or 'aggression, humans' or 'aggression, animals' yields a staggering 54,964 articles on 'human violence' since 1897 (491 articles per year on average), compared with only 1204 articles on 'animal violence' since 1968 ( 29 articles per year on average). There have been 21,925 articles on 'human aggression' since 1947 (353 articles per year on average) and 9691 on 'animal aggression' since 1962 (206 articles per year on average). A time-line of these publications from 1985 to 2007 is summarized in Figure 1. It is evident from the figure that the literature on violence in animals is sparse. In line with the above, violence has indeed been shown to be relatively rare in wild animal populations as well as amongst humans, which adds indirectly to the challenges (Mathews, 1964; Moffitt, 1993; Nagin and Tremblay, 1999; Suomi, 2003; WHO, 2004; Wrangham et al., 2006; de Boer et al., 2009). However, the publication discrepancy between human and animal violence could also stem from the lack of an appropriate definition for violence in animals. The terms 'violence' and 'aggression' are often used interchangeably across the human and animal literature without resolving what, if any, are the constructs or operational definitions unique to violence and adaptive aggression. Understanding the key differences between violence and adaptive aggression may thus help one to bridge the gap between the human and animal literature on violence (Haller et al., 2006).

\section{BEHAVIORAL SEOUENCE LEADING TO AGGRESSION OR VIOLENCE}

In our opinion, identifying valid animal models for pathological aggression first requires an appropriate operational definition for violence. The focal point of distinction between violence and adaptive (that is functional) aggression relies on the behavioral sequence or interaction dynamics between two or more conspecifics in combat. In other words, the sequence of agonistic behaviors between minimally an aggressor and its opponent that leads predictably to either adaptive aggression or violence is the key. Ideally, animal models for violence are not subjected to any inhibitory control, thus losing any adaptive function in social communication (Miczek et al., 2004; Haller and Kruk, 2006; Nelson and Trainor, 2007). Here, we outline the behavioral criteria we consider foremost in identifying intense/injurious aggression that may exceed normal species-typical levels and patterns. The following sections give a putative chronological sequence of behavioral components in the 

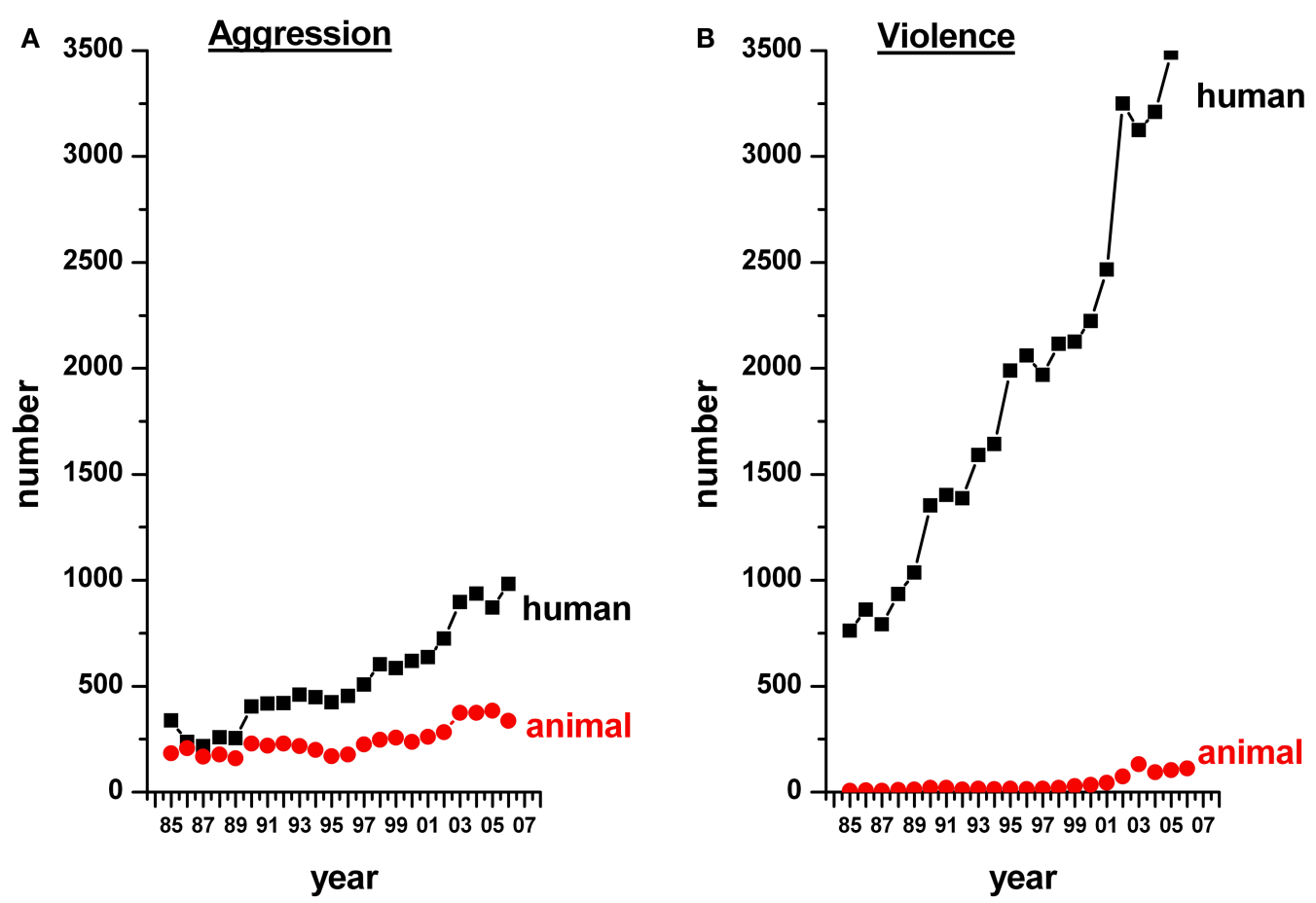

FIGURE 1 | A time-line showing the number of articles published from 1985 to 2007 on aggression (A) and violence (B) in humans (black) and other animals (red). Note that studies on animal violence lag considerably behind those on human violence.

encounter between a resident male and an intruding conspecific, a classic conflict situation in many animal species. We examine each of these components in depth, to arrive at an operational definition of violence based on the current human and animal literature.

\section{INTENT}

To resolve conflicts effectively, animals require well-developed sense organs and the ability to use sensory information to assess the opponent and the environment. Encountering a potential opponent, even at a distance, may involve estimation of the species, sex, social/reproductive status, fighting ability and motivation of the opponent via a complex, dynamic array of cues (sights, sounds, smells and physical contact) and their interaction with the internal state of the focal animal (Huntingford and Turner, 1987). In a typical aggressive combat situation under normal conditions, this estimation process may reveal itself as a series of pauses/movements over a brief time-period. Meloy (1988) has suggested that predatory behavior in cats (or its equivalent in humans, namely the instrumental form of violence) may lack this sensory ability to acquire and process information without any sympathetic arousal. Thus, violence involves an altered state of intention to attack devoid of any sensory feedbacks, as seen from short attack latencies.

\section{RITUALIZATION}

Most agonistic encounters are stepwise (Archer and Huntingford, 1994), where the processed information leads to actions that do not involve direct head-on physical contact, regardless of the familiarity of the opponent (Preuschoft and van Schaik, 2000). These lowkey, transient and energetically cheap (Dawkins and Krebs, 1978) agonistic actions often increase the apparent size of the animals concerned and/or expose their weapons. Agonistic encounters resolved without overt fighting are thus said to be 'ritualized'. Animals which possess the equipment for offense/defense exhibit aggressive behavior (Scott, 1958) but fighting amongst conspecifics is minimized by way of such ritualized behaviors, so that fights never end fatally and are generally no more than trials of strength followed by disengagement and rapid withdrawal by the weaker individual (Mathews, 1964). It is likely that violence bypasses the requirement for such ritualized behaviors, owing to altered motivations, which may be intentional or unintentional and are predominantly harm-oriented.

\section{PRE-ESCALATION}

Physical contact follows ritualization and often involves pushing, pulling or tail-beating contests, referred to as threat displays. These interactions involve the exploration/marking system (activated particularly by unfamiliar scents), as well as grooming (activated by secretions on the skin surface). In the wild, the opponents faced can be formidable and hence the deliberations during pre-escalation could be important even for a dominant animal. Such a rich behavioral repertoire potentially allows opponents to assess their relative strength, which may lead to the weaker one giving up before escalation takes place. This establishes dominance relationships amongst conspecifics (Huntingford and Turner, 1987). Submission in many group-living species inhibits aggression and gives rise to subsequent affiliative interactions (Preuschoft, 1995). Violence can thus be characterized by a marked lack of information about the opponent, which is followed by a (species-specific) reductionist 
behavioral repertoire that lacks or displays inadequate threat behaviors and displays in general. Consummatory behaviors such as attack or escalated aggression may supersede ritualistic threat behaviors in violent individuals.

\section{ESCALATION}

In animal aggression, ritualization and pre-escalation are followed by a stage marked by energetic and potentially dangerous actions (such as biting, kicking and striking). This progressive increase in the intensity of the conflict is described as escalation (Huntingford and Turner, 1987). Conflicts can be resolved by one participant retreating at any point in the escalation sequence, so that full-scale physical attack is not a necessary component of all animal fights. These conflicts are often short, rapid and aimed at delivering the status of dominance and the ability to acquiring resources in the group. Violence, however, may entail pronounced escalatory behavior, characterized by longer or more frequent consummatory actions or both, targeting an opponent and its vulnerable body parts regardless of its subordination or submissive status.

An all-out tooth and claw fight may occur in exceptional circumstances, for example when resources (food/mates/space) are limited, or when competitors have the same levels of motivation, or when they are willing to risk their ability or status (as expected in the declining phase of a population), or when they have imperfect information about their power asymmetry (Smith and Parker, 1976). Such conflicts may have consequences for the regulation of population size, by compromising the reproductive success of subordinates or affecting mortality, emigration and/or the reestablishment of dominance hierarchies (van Oortmerssen and Busser, 1987). Experimental instances of violence in the lab are thus expected to be relatively rare when the animals are provided with food (ad libitum), partners and territory and therefore face no substantial environmental challenges.

\section{POST-ESCALATION}

Given the long-lasting negative consequences of conflicts in general, the post-escalation phase is integral in individuals of many group-living species regardless of their familiarity. Establishment of stable hierarchical societies or family groups is feasible only due to post-conflict affiliative behaviors (Preuschoft and van Schaik, 2000). Conflict resolution often occurs through affiliative contacts like gentle touching, as seen in humans, rhesus monkeys and horses (Drescher et al., 1980, 1982; Feh and de Mazieres, 1993), and allogrooming, as seen in monkeys (Boccia et al., 1989; Aureli et al., 1999). Violence typically lacks any post-conflict appeasement behaviors. Submission by a weaker opponent may not be pro-inhibitory, but in fact may provoke further violence. In other words, withdrawal behaviors might be disproportionately lower to the observed consummatory behaviors in a violent conflict.

\section{CONTEXT DEPENDENCY}

Agonistic interactions are often modulated by the environment (e.g., known/unknown territory; home/neutral environments) and by the opponent's status, sex (e.g., male-male agonistic encounters are more common than inter-sexual conflicts) and familiarity. Escalated fighting is less frequent among familiar individuals than strangers (Karavanich and Atema, 1998), allowing the former to save the time and risks associated with assessment and escalation. These benefits may help to stabilize associations among many group-living or territorial animals, including those that are submissive (Preuschoft, 1995). Context-independent attacks are often seen in mammals in that they aim human habitats when their own habitats are threatened (Corbett, 1957). Violent human offenders are also known to attack and indulge in unaccepted norms and practices including sexual/vocal/physical abuses that are inappropriate and context-independent (Agnew, 1998). Violence may be context-independent, i.e., incapable of discriminating between opponents or environmental contexts.

In summary, adaptive aggression seems to be a functional, dynamic, flexible yet structured behavior within certain limits, achieved by a pattern of constrained actions, reactions and social signals between the opponents in conflict. As such, it appears to involve strong inhibition against causing harm, unless strictly necessary. Violence, on the other hand, seems highly disinhibited and indiscriminate to a conspecific. Violence can therefore be considered an aggressive behavior that is out of control (uninhibited), out of content (pattern and structure of the agonistic combat) and out of context, making it qualitatively different from other forms of aggression. Inclusion of these criteria in aggression models will add to their validity, thereby expanding our knowledge of the underlying neurobiological correlates of pathological and violent forms of human aggression.

\section{ANIMAL MODELS OF VIOLENCE}

Now that we have defined violence and adaptive aggression, we move on to consider some of the more important animal models in detail and describe how they have contributed to our understanding of violence. Replication of feral violence (as described in the introduction) in the lab has been a multidisciplinary effort, in that much of the information about violence and aggression has come from manipulative studies at neurophysiological, environmental, neuropharmacological and genetic levels. We describe some of these studies below.

\section{NEUROPHYSIOLOGICAL MANIPULATIONS}

Neurophysiological manipulations, involving electrical stimulations and lesions of the brain, were the preliminary experimental methodologies for studying the brain mechanisms of aggression in the early 19th century. Several methodological techniques were used, from gross regional ablations (e.g., decerebration) to focal lesions and electric stimulations of several brain regions in cats, monkeys, dogs and rats. Siegel (2004) provides an excellent review of these approaches. In particular, identification of classic defensive rage responses and predatory attack behavior models in cats contributed significantly to the understanding of the neural control of aggressive attack in the last century. The rage response has been shown to share physiological (sympathetic arousal, e.g., increase in heart rate and blood pressure) and behavioral (repertoire limited in time or to events of short duration; ritualized behavioral postures prior to the consummation act) features with the impulsive or unplanned human violence seen in intermittent explosive disorder (Meloy, 1988). The predatory attack model seems to overlap with human psychopathy in that it was not sympathetically mediated, positively reinforcing to the self and hence compulsive, 
planned with precise and intense delivery to the victim, and with no apparent threat in the vicinity (Meloy, 1988). The human counterpart also involves focusing on the target by filtering out sensory information, in much the same way as a cat does when focusing on its prey (Meloy, 1988).

Electric stimulation of specific brain regions were also carried out subsequently in rats, triggering biting attacks on the neck, head or back (Woodworth, 1971; Koolhaas, 1978) coupled with paw kicks to the flank, clinch fights and attack jumps (Kruk et al., 1979; van der Poel et al., 1982; Lammers et al., 1988). The electrical brain-stimulated (hypothalamic activated attack, HAA) rat model of aggression and the glucocorticoid-deficient rat model (described later on) has also helped in identifying additional behavioral parameters that include differential contexts, such as the resident's response to the opponent's status (dominant/subordinate; anaesthetized/dead) and sex (male/female).

Thus, neurophysiological studies in cats and rodents laid the foundations for the analysis of offensive and defensive components of violence and aggression with some clinical validity to human violence. These neurophysiological manipulations additionally also paved the way to the discovery of several neuroanatomical substrates of violence and aggression in the brain, amongst which the prefrontal cortex, hypothalamus and periaqueductal gray (PAG) deserve special attention.

\section{Neural substrates of violence/aggression}

The prefrontal cortex has been identified as a primary inhibitory center of aggression and violence in both humans and animals. The earliest reports on its role as a modulator came from Gage's accidental prefrontal lobotomy leading to uninhibited child-like behavior in the intellectual abilities and passions of a strong man (Harlow, 1848, 1868). Stimulation of medial/lateral (orbital) prefrontal cortex for instance, caused profound suppression of predatory attack and defensive rage by increasing the latencies to attack (Siegel et al., 1974, 1975). In rats, bilateral thermal lesions in the ventrolateral prefrontal cortex increase the duration of lateral threats (de Bruin et al., 1983; de Bruin, 1990). Recently, PET studies have confirmed the prevalence of prefrontal cortex malfunctioning in highly aggressive people (Enserink, 2000; Raine et al., 2000; Lee and Coccaro, 2001).

The classic rage response described earlier has been shown to be elicited by electric activation of the medial hypothalamus, ventral tegmentum, stria terminalis, and PAG in the cat (Siegel, 2004). Predatory attack behavior or quiet attack (Wasman and Flynn, 1962) can be elicited by electric stimulation of the lateral hypothalamus/midbrain. This has also been shown in rats that have been electrically stimulated in the hypothalamus (Koolhaas, 1978; Kruk et al., 1979; Kruk, 1991; Haller et al., 2001; Halasz et al., 2002). Several neurological disorders in humans implicate the involvement of hypothalamus, PAG and other limbic structures in the control of aggression and rage (Siegel and Victoroff, 2009). These include temporal lobe epilepsy, sclerosis of the temporal lobe, and tumors of the temporal lobe, hypothalamus and other limbic structures. At a pre-clinical level, defensive rage in cats has been proposed to be mediated by a glutamatergic neurotransmitter pathway from the amygdala and hypothalamus to the PAG, which in turn leads to an exaggerated response to stimulation
(Siegel et al., 1999; Yao et al., 1999). However, these models require further behavioral validation to ascertain the pathological nature of aggression.

\section{ENVIRONMENTAL MANIPULATIONS}

Early lab studies in rodents were primarily non-physiological, non-ecological manipulations including social isolation, electricshock-induced attack, and tube restraint attack (Brain, 1989). Later, manipulations used ecologically more relevant human contexts including repeated winning or losing experiences (Andrade et al., 1989) and several other aggression-inducing or stressful conditions such as frustration, social instigation and mild uncontrollable stress. Stressful experiences, especially in early life, have been strongly associated with violence and anti-social behaviors in humans (Deater-Deckard and Plomin, 1999; Kendler et al., 2003) and macaques (described under Section 'Genetic Manipulations'). Since the 1970s, extensive environmental manipulations have been carried out to induce or enhance aggressive behavior, particularly in rodents. These are described below.

\section{Aggression induced by social isolation}

Abnormal behaviors seen in adolescents and adults are considered to be causally related to disruption of early attachment (Bowlby, 1969, 1988; Ainsworth et al., 1978; Kraemer, 1992), a theory supported by studies in rhesus monkeys (Harlow et al., 1971). Similarly, seclusion in prison inmates and asylum patients is associated with pathological behaviors (Farrell and Dares, 1996). Social isolation was one of the earliest and most frequently used methodological approaches to induce or enhance fighting in animals as well (Brain, 1989). Male rodents were isolated for 2-8 weeks or even longer, and subsequently confronted with a group-housed conspecific in an unfamiliar test arena or in the isolate's home cage (Vekovischeva et al., 2007). Isolated subjects were found to display enhanced and prolonged aggression (Brain, 1989). Expression of inappropriate adult aggressiveness is also observed in a wide variety of animal species after maternal separation or early-life social isolation (Veenema, 2009).

\section{Aggression induced by provocation}

Prior exposure to a myriad of acute or chronically applied stressful stimuli is known to induce aggression in humans (Craig, 2007; Herrenkohl et al., 2007), as well as in experimental animals when tested during a subsequent resident-intruder interaction (Haller et al., 2004). Acute provocation strategies have been used in rodents, for example by applying intensely noxious and/or painful stimuli like electric shocks just before or during a brief social confrontation (Brain, 1989). More recently, the exposure of mice to an unpredictable chronic mild stress protocol for several weeks was reported to enhance levels of aggression (Mineur et al., 2003).

Frustrative non-reward represents a procedure with exceptional effectiveness in provoking very high levels of aggressive behavior in fish, birds, rodents, pigs, monkeys and humans (Dollard et al., 1939; Azrin et al., 1966; Thompson and Bloom, 1966; Cherek and Pickens, 1970; Arnone and Dantzer, 1980; Miczek et al., 2002, 2003; Leary et al., 2006). Organizational and management research has focused on (mal)adaptive work behaviors and implicates organizational aggression as a counter-response to frustration (Fox and 
Spector, 1999). Frustration (especially when unjustified) has also been shown to trigger aggressive behavior in college students (Dill and Anderson, 1995). Aggressive driving is considered a syndrome of frustration-driven behaviors (Shinar, 1998), while video games involving intense competition often lead to frustration and aggression (Anderson and Ford, 1986).

The sudden and unpredictable omission of reinforcement just before confrontation with an opponent enhances aggressive behavior in animals. One of the first studies was carried out by Pavlov (1927), who conditioned dogs to associate the arrival/withholding of food with a specific geometrical shape. However, when the different shapes presented were manipulated to look alike, the subject became confused and eventually aggressive, apparently out of frustration. A resident animal can also be provoked by placing an instigator or opponent into its home cage behind a protective screen for a short time prior to the actual physical confrontation. This is known to accelerate and/or enhance aggressive attacks. This socalled social instigation/provocation or priming procedure has been successfully demonstrated in mice (Fish et al., 1999), rats (Potegal, 1992) and hamsters (Potegal et al., 1993).

\section{Aggression heightened by anticipation or experience}

This procedure is based on the induction and learning of aggressive behavior upon repeated stimuli that can reinforce operant responding in humans and other animals (Thompson, 1964; Connor, 1974; Potegal and Einon, 1989; McSweeney and Swindell, 2002). Berkowitz $(1984,1989,1993)$ has proposed a 'cognitive neoassociation model of aggression' in which, when people are repeatedly exposed to aggressive situations (for instance, video games, Dill and Dill, 1998), detailed and inter-connected aggressive thought networks are created. These authors proposes that playing violent video games leads to the learning of violent behaviors as an acceptable way of solving problems and may desensitize the participants to violence.

Similarly, animals are motivated to perform an operant (nosepoke or lever-press response) where the opportunity to get access to an opponent and display aggressive behavior serves as the reinforcer (Miczek et al., 2002). This indicates that, even though aggressive confrontations may be extremely stressful or anxiogenic, the performance of aggression can function as a potent positive reinforcing event (Miczek et al., 2002, 2004; Couppis and Kennedy, 2008). Providing an animal with repeated positive (i.e., winning) aggressive experiences in its home cage generally leads to an increase in aggressiveness (Kudryatseva, 2000; Kudryatseva et al., 2000). After extended repeated winning experiences, certain individuals may start to attack with very short latency, high intensity and high frequency and without regard to signals of submission, often leading to severe wounding of the opponent (Hsu et al., 2006).

\section{NEUROPHARMACOLOGICAL MANIPULATIONS}

Scientists began to identify the neurochemical substrates behind violence since the 1960's. Low concentrations of the brain neurotransmitter serotonin (5-HT) were linked with high aggression in mice; 5-HT turnover to the metabolite 5-HIAA (as indicated by low levels in the cerebrospinal fluid) were linked to violence in humans (Maas, 1962; Garattini et al., 1967; Asberg et al., 1976; Brown et al., 1979; Linnoila and Virukkunen, 1992). In particular, low 5-HIAA levels have been found to predict explosive aggression and impulsive violence in conduct-disordered boys and have been associated with social incompetence (Siever and Trestman, 1993). This neurochemical condition has also been reported in arsonists and has been shown to be associated with high rates of criminality, alcohol dependence and premature death due to murder (Lewis, 1991; Berman and Coccaro, 1998). Reduced blood platelet 5-HT binding or blood tryptophan levels have also been linked with a life history of violent behavior (Brown et al., 1979; Linnoila et al., 1983; Maes et al., 1993). Primates, including the rhesus macaques mentioned earlier, have also been shown to display anti-social behavior patterns with deleterious impulse-control deficits of demonstrable trait-like stability throughout life, associated with low 5-HIAA levels (Higley et al., 1991). Other behaviors found to be associated with low 5-HIAA levels include unrestrained aggression, impulsive risk-taking, excessive alcohol intake and most severe forms of violence leading to trauma and early death. More recently, several pharmacological manipulations have been used, both centrally and peripherally, to study various neurotransmitter systems including 5-HT and other related neurochemical circuitries. A few selected studies are described below.

\section{Aggression induced by serotonin depletion}

Many studies have sought to identify a causal relationship between low 5-HT levels and aggression, using a variety of manipulations including dietary restriction of the 5-HT precursor amino acid tryptophan, inhibition of 5-HT synthesis by administration of the tryptophan hydroxylase (TPH) inhibitor $p$-chlorophenylalanine (PCPA), and destruction of serotonergic neurons by administration of the serotonin neurotoxin 5,7-dihydroxytryptamine (5,7-DHT). Chronic tryptophan deletion in rats increased shockinduced aggression (Kantak et al., 1980a,b) and muricidal behavior (Gibbons et al., 1978). Aggression was also acutely increased in human male subjects, particularly those with high trait aggression, when they were administered tryptophan-free amino-acid mixture (Chamberlain et al., 1987; Cleare and Bond, 1995; Pihl et al., 1995; Bjork et al., 2000; McCloskey et al., 2009). This was also observed in rodents (Bell et al., 2001). Rats in which serotonin neurons were lesioned with 5,7-DHT, showed more shock-elicited aggression and muricidal behavior (Breese and Cooper, 1975; Hole et al., 1977; Kantak, 1981; Kantak et al., 1981; Vergnes et al., 1988). An increase in muricide and offensive aggression was also observed when rodents were injected with PCPA (Miczek et al., 1975; Paxinos et al., 1977; Gibbons et al., 1978; Valzelli et al., 1981; Sewell et al., 1982; Albert et al., 1985; Ieni and Thurmond, 1985; Molla-Hosseini, 1985; Vergnes et al., 1988; Keele, 2001).

\section{Aggression heightened by alcohol}

Alcohol ingestion has also been shown to induce aggressive behavior in humans. In the United States between 1993 and 1998, 30-40\% of crimes committed involved an offender who had consumed alcohol prior to the crime (Greenfield and Henneberg, 2000). Crosscultural studies have shown a greater-than-chance involvement of alcohol in homicide and violent crime (Murdoch et al., 1990). A meta-analysis of experimental research on alcohol and aggression suggests a general increase in aggression after consuming alcohol, especially for men (Bushman and Cooper, 1990; Bushman, 1997). Not only is alcohol associated with an increase in aggressive 
behavior, there is also some evidence to suggest that the effects of alcohol consumption may contribute to the escalation of conflict and increased risk of injury when aggression does occur (Martin and Bachman, 1997; Sharps et al., 2001; Brecklin and Ullman, 2002). Alcohol-heightened aggression (AHA) has been modeled in alcohol-treated rodents, which show frequent attack bites compared to controls (Fish et al., 1999; Miczek et al., 2004).

\section{Aggression induced by low glucocorticoids}

Glucocorticoid hypofunction has also been associated with abnormal aggression and violence. Habitually violent offenders with anti-social personalities show lower levels of plasma glucocorticoids than healthy subjects and non-habitual violent offenders (Virkkunen, 1985). It has also been shown that plasma glucocorticoid levels are inversely associated with aggressiveness in children with conduct disorder (McBurnett et al., 2000). Low basal levels and hyporesponsiveness of plasma glucocorticoids are associated with persistent aggression in humans (Pajer et al., 2001; Kariyawasam et al., 2002) and this finding has also been documented in dogs and rainbow trout (Hennessy et al., 2001; Pottinger and Carrick, 2001). Haller et al. (2001) generated adrenalectomized (ADxR) rats supplemented with subcutaneous glucocorticoid pellets to ensure a low and constant level of glucocorticoids in the plasma. These rats showed several of the salient features described in the sections earlier, including attacks aimed at vulnerable parts of the intruder's body, high A/T ratios and poor social exploration, supportive of a qualitative difference between violence and adaptive aggression.

From the above manipulations (environmental/pharmacological), one can infer that many factors promoting aggression in humans (psychological, alcohol-induced, low glucocorticoid levels) have similar effects in animals, which is suggestive of shared underlying biological mechanisms.

\section{GENETIC MANIPULATIONS}

Acute (emotional) stress and social subordination has been shown to induce an interplay of 'gene' $\times$ 'environment' interaction in heightening aggression, primarily via the 5 -HT system. This is translated as a downregulation of the activity and expression of specific 5-HT components, namely monoamine oxidase A and B (MAO A, B) and serotonin transporter (SERT). Brunner et al. (1993) showed the segregation of a complex behavioral syndrome (including impulsive aggression and dysfunctional sexual attitude) with a nonsense mutation resulting in null activity of the enzyme MAO A in males from a Dutch pedigree. Possession of a low-activity allele of the MAO genotype was associated with anti-social behavior upon maltreatment (Caspi et al., 2002). Maladaptive social behaviors, such as those seen in schizophrenia, suicidal depression, cluster-B personality disorders and attention deficit/ hyperactivity disorder (ADHD), are associated with impulsivity and with the SERT gene-linked polymorphic region (5-HTTLPR allele) - the short/short (SS), short/long (SL) genotypes, and are only exacerbated by environmental adversities and individual life-history experiences (Retz and Rosler, 2009). Recently a 'bottom-up' molecular genetic approach (i.e., single-gene knock-out and transgenic over-expression) was used to assess the polygenic nature of aggression and violence. This approach has so far identified at least 75 genes as playing a role, including the nitric oxide synthase (NOS-I) gene (Reif et al., 2009), Dopamine receptors $\mathrm{D}_{2}$ gene variants and Dopamine transporter (Guo et al., 2007). For detailed reviews, see Miczek et al. (2001), Nelson and Chiavegatto (2001), and Retz and Rosler (2009).

The earliest evidence regarding the genetic basis for violence came from heritability studies (Blonigen and Krueger, 2006). Breeders selected either for docility or for a strong tendency to attack, as seen for example with dogs and chickens. These informal observations and a few systematic studies of the patterns of inheritance for violence and aggression carried out earlier (Yerkes, 1913; Utsurikawa, 1917; Coburn, 1922) indicate that this complex behavioral trait is influenced genetically. The alternative, classic 'top-down approach' genetic approach focused on selective breeding for aggression in rodents, as in the Turku Aggressive (TA) and Turku Non-Aggressive (TNA) mice (Lagerspetz, 1961), SAL and long attack latency (LAL) mice (van Oortmerssen and Bakker, 1981), and the North Carolina Aggressive (NC900) and North Carolina Non-Aggressive (NC100) mice (Sandnabba, 1986). Box 1 offers a detailed description of the selection of these mice. In particular, the SAL mice, selectively bred from a wild population from Groningen, the Netherlands, have been strongly associated with violence over the years (discussed below in Section 'SAL Mice as an Animal model for Violence').

Despite the availability of several approaches and manipulations in animals (as described above), most of these studies have failed to tackle the controversial issue of defining violence and its delineation from adaptive aggression. Their focus has primarily been on documenting the different types of violence or aggression displayed. For instance, as mentioned earlier, feline models have revealed different forms of violence, namely predatory attack or instrumental violence and defensive rage or affective aggression. Rodent models focus on specific physiological aspects of violence (basal heart rate and glucocorticoid response to stress) leading to the identification of hypo- and hyper-arousal-driven forms of aggression. Several studies define offensive and defensive forms of aggression but none of these models helps to elucidate the possible distinction between violence and aggression. Several of the pharmacological models aimed at 5-HT depletion have often proved contradictory, in that the aggression outcomes were inconsistent. For a few other models of induced aggression (e.g., frustration, social instigation and other pharmacological manipulations aimed at 5-HT and other neurotransmitters), it is highly questionable whether this induced aggression is pathological or not. Thus, there is a pressing need to identify those animal manipulations that offer face (symptomatological), construct (etiological and neurobiologi$\mathrm{cal}$ ) and predictive (pharmacological) validities to human violence. de Boer et al. (2009) have argued that most of the manipulations described above lack face validity, owing to controversies regarding the operational definition of violence and its distinction from other forms of animal aggression.

\section{SAL MICE AS AN ANIMAL MODEL FOR VIOLENCE}

Differences between violence and adaptive aggression were recently established using SAL, TA and NC900 mice, genetically selected for high aggression (see Box 1 for details). The males from these mouse lines were compared for their agonistic behaviors when subjected to a resident-intruder paradigm based primarily on social 


\section{BOX 1}

TA/TNA: Lagerspetz (1961) developed the Turku aggressive (TA) and theTurku Non-aggressive (TNA) lines from an out-bred colony of Swiss albino mice in Turku, Finland. The mice from each line were kept in different rooms, weaned at 21 days of age and individually housed. At 60 days of age, males were tested for aggression in a standard 7-min dyadic test in a neutral arena (clean glass container) against standard opponents (pretested nonaggressive animals). The aggressive behavior was rated on a 7-point scale. Males with high aggression scores were used for breeding together with females, sisters of high-scoring males, avoiding brother-sister mating (Lagerspetz and Lagerspetz, 1971). The selection produced an aggressive line in the 11 th generation, while the other line was already non-aggressive in the first generation. However, mice that showed some aggression were always present in the TNA line.

$S A L / L A L:$ The second independent selection was carried out in a colony randomly bred from wild house mice (Mus musculus) trapped in a mansion near Groningen, the Netherlands in the winter of 1971 (van Oortmerssen and Bakker, 1981). Four males and three females (founder members) were caught about 6 months after a crash of the wild population, which is usually marked by high mortality/dispersal conditions and poor physical health in the residents (Busser et al., 1974; van Oortmerssen and Bakker, 1981). The selection started from descendents of these founder members in the summer of 1973, which marked the transition from increase to peak phase of both aggression and the mice population in a parallel semi-natural population study. To breed the short attack latency (SAL) and long attack latency ( $L A L$ ) lines, mice were kept after weaning (3-4 weeks) in unisexual litters until sexual maturity (7-9 weeks), at which point they were male-female paired in small cages. At the age of 14 weeks, each male mouse was tested for aggression in a resident-intruder test carried out in a large cage. The experimental animal was the resident and was tested with a naive albino intruder (MAS-Gro). The attack latency, i.e., the latency to first attack by the resident, was recorded. Later studies confirmed that this parameter correlates negatively with other parameters of aggression (Benus et al., 1991). The final score used to define a SAL or a LAL mouse was the attack latency score (ALS), i.e., the average of the attack latency times measured over three consecutive days of testing. When an animal attacked as soon as the partition was removed, it was considered to be short attack latency (SAL) mouse. When the mouse did not attack within $600 \mathrm{~s}$, it was considered long attack latency (LAL) mouse, and the test was stopped.

NC900/NC100: Cairns et al. (1983) selected a base population of out-bred NCR mice in North Carolina, USA, using a dual criterion, namely increased attack and heightened reactivity to stimulation. A highly aggressive line and an immobile line were created (I-lines). A second attempt focused only on aggression as a selection criterion and this selection generated the NC900 and NC100 lines. The testing procedure was as follows: after weaning at 21 days, the mice were housed in relative isolation. At 45 days of age, aggressiveness was measured in a standard 10-min dyadic test carried out in a neutral Plexiglas box, after 5 min of adaptation in which no physical contact was allowed. The attack frequency (in 5-s intervals) and the attack latency were measured and combined with 31 other variables to give a scoring system up to 900 . The result was the selection of an aggressive line, NC900, and a non-aggressive line, NC100. instigation and experience-dependent aggression (as described under 'Environmental Manipulation' section). The resident-intruder paradigm with no escape routes is an artificial situation, aimed at increasing aggression levels in these mouse lines. We applied Markov Chain analysis to analyze the behavioral sequence of the agonistic repertoire displayed by the resident, both when it was alone and when it was with the docile intruder. The frequency of transitions from one behavior to another (exclusively the residents or the resident-intruder behavioral exchanges) was used owing to their high occurrences in the highly aggressive mice. Similar studies have been carried out in characterizing alcohol-induced heightened aggression in rats (Miczek et al., 1992). Behavioral testing has been described in detail elsewhere (Caramaschi et al., 2008a; Natarajan et al., 2009a).

\section{SAL IS QUALITATIVELY DIFFERENT FROM TA AND NC900 MICE}

Several behavioral features of SAL, TA and NC900 mouse lines were derived with reference to the criteria described in section 'Behavioral Sequence Leading to Aggression or Violence. Most of our understanding of violence and its delineation from aggression has stemmed from male-male interaction studies carried out in these mice.

\section{Intent}

All the high-aggressive mouse lines displayed consistently low latencies of attack, while the low-aggressive lines displayed high attack latencies (Caramaschi et al., 2008a; Natarajan et al., 2009a). In particular, the SAL mice had the lowest attack latencies right from day 1 when compared to the TA or NC900 mice lines. However, repeated winning experiences lowered the attack latencies in TA and NC900 mice subsequently (Caramaschi et al., 2008a).

\section{Ritualization and pre-escalation}

Using behavioral kinetograms, Natarajan et al. (2009a) showed that the SAL mice investigate their opponents less readily than TA, NC900 or the low-aggressive mouse lines (Figure 2). Earlier, Halasz et al. (2002) reported heightened A/T ratios in the ADxR rats (2002), suggestive of immediate consummatory action without appropriate ritualistic/pre-escalatory behaviors. High A/T ratios were also shown in SAL mice (Caramaschi et al., 2008a). Natarajan et al. (2009a) modified A/T ratios to incorporate 'chase' behaviors as part of the consummatory process as the threat $/($ attack + chase $)[\mathrm{T} /(\mathrm{A}+\mathrm{C})]$ ratio. Low $\mathrm{T} /(\mathrm{A}+\mathrm{C})$ ratios were observed in SAL mice, suggesting a similar lack of ritualistic/pre-escalatory behaviors (Natarajan et al., 2009a). Despite showing lower attack latencies, TA and NC900 mice still displayed ritualistic and pre-escalatory behaviors and were inhibited by the opponent's submissive behavior, as shown by a higher magnitude of their own transitions to non-social exploratory behaviors (Figure 2, right half).

\section{Escalation}

The measures of offense used for all three high-aggressive mouse lines were duration and frequency of attack, chase and threat behaviors. Interestingly, the lines did not differ significantly for any of these behaviors. This confirms the idea that offense is a measure of 
A

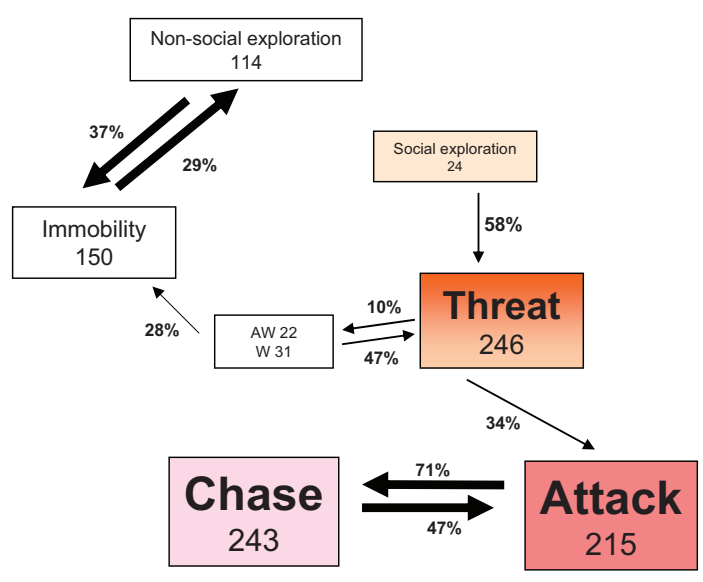

NC900

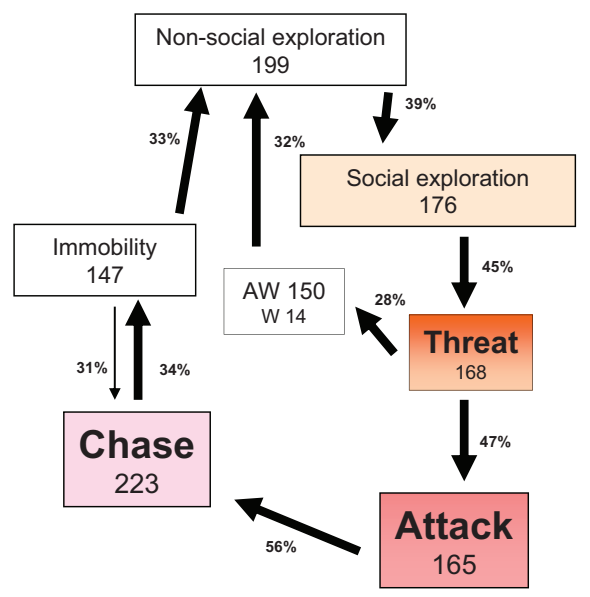

B

\section{SAL}

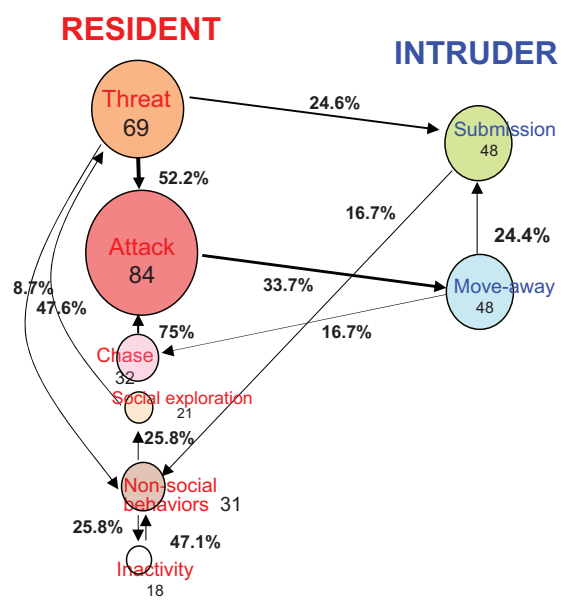

FIGURE 2 | Behavioral kinetograms of the short attack latency (SAL)

(A) and NC900 (B) mice. The thickness of the arrows depict the degree of the probability. Thick arrows represent the highest probability. Thin arrows represent the lowest probability. AW stands for approach withdrawal. W stands for withdrawal. The top panel describes the resident male's agonistic behavior while the bottom panel describes its interaction with an opponent. Note that the SAL mice (left half) display a predominant offense-oriented locked-in attack $\rightleftharpoons$ ( chase

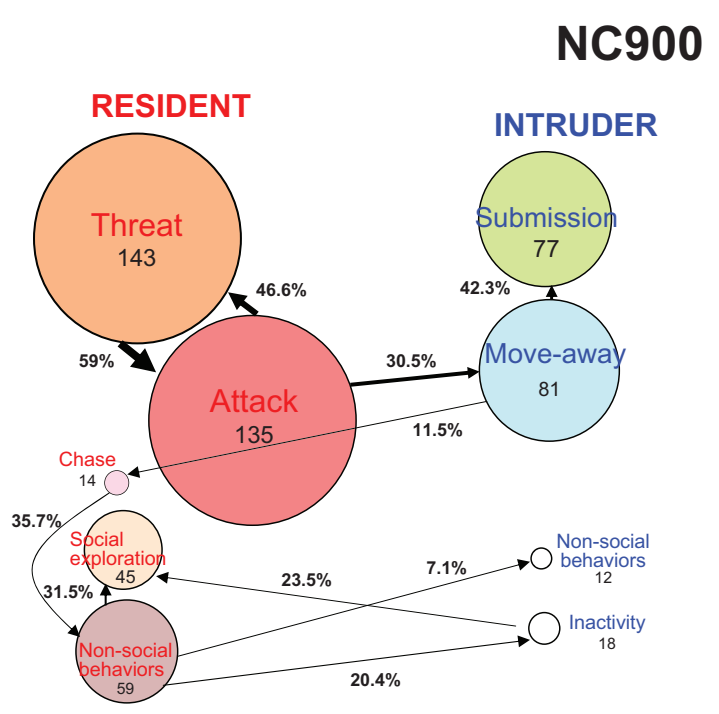

transition. The NC900 mice (right half) display an equal propensity of almost all behavioral transitions suggestive of a rich, inhibitory and opponent-sensitive adaptive aggression. The numbers within the box represent the frequency of occurrence of the behavior concerned while the numbers over the arrows represent the frequency of occurrence of the behavioral transitions concerned. The size of the boxes increases with the frequency and vice-versa. Adapted from Caramaschi et al. (2008a) and Natarajan et al. (2009a). hyper-aggression at least in these mice (Natarajan et al., 2009a). The SAL mice were, however, shown to possess a stable and diverse display of extremely offensive behavioral transitions across three successive days of agonistic combat, in comparison to the moderate and stable NC900 line and the declining TA line (Natarajan et al., 2009b). An increased frequency and duration of offensive behaviors was also salient in rodents that showed AHA and those that were modeled for social instigation, frustration as well as in those that were administered midozolam (Miczek et al., 2003, 2004; Fish et al., 2005).
SAL mice failed to respond to the inhibitors' submissive behavior, as seen by the locked-in attack-chase offensive interplay when compared to TA and NC900 mice. SAL mice also showed more attackchase behavioral transitions than NC900 (refer Figures 2A,B) and the least withdrawal behavior, and hence showed a high ratio of withdrawal to offense rates (O/W, Natarajan et al., 2009a). Earlier, Haller et al. (2006) showed that a third of SAL attacks targeted the vulnerable parts of the opponent's body, compared to the lowaggressive counterpart LAL, pointing to the potentially lethal nature 
of their attack strategies. This is similar to the HAA rats (Kruk et al., 1990) and ADxR rats, which attacked the head of the opponent. The latter were also shown to preferentially attack vulnerable parts (head, throat and belly) of their opponents, up to $70 \%$ of the total number of attacks. Such attacks were rare in control rats (only between 3-10\%, Haller et al., 2004).

\section{Post-escalation}

Although none of these high-aggressive mouse lines were shown to groom their male opponent after a conflict, it was evident that TA and NC900 lines resorted to innocuous cage exploration after a brief period of escalatory behaviors (Figure 2, right half). The SAL mice showed more transitions from offensive behaviors to immobility, which is suggestive of physical exhaustion (Figure 2, left half) rather than sensitivity to the attacked opponents (Natarajan et al., 2009a). Unlike SAL, TA and NC900 interactions with the intruder were further characterized by a rich repertoire of submissive and moving-away behaviors (Caramaschi et al., 2008a; Figure 2, bottom panel).

\section{Context-dependency}

The SAL mice failed to discriminate between anaesthetized mice, free-moving mice, and female partners regardless of their familiarity or estrous status (Caramaschi et al., 2008a; Natarajan et al., 2009a), as has also been observed in HAA (Kruk et al., 1990) and ADxR rats (Haller et al., 2004). The partner offense behavior in particular has been observed to worsen with age in SAL mice, but not in TA and NC900 mice (personal observations).

In summary, the aggressive behavior displayed by SAL mice is in line with the definitions of violence put forth in Section 'Behavioral Sequence Leading to Aggression or Violence'. The above findings are also suggestive of a 'qualitative' behavioral difference between violence and adaptive aggression. de Boer et al. (2009) found a similar pattern in the WTG rats, characterized by early attack frequency, long and frequent consummatory behaviors, and indiscriminate attacks on female conspecific partners and anesthetized male intruders. WTG rats were also shown to focus their attacks primarily on the vulnerable parts of the opponent's body, as with the SAL mice and the ADxR rats. It is also apparent that conventional comparison of the behavior of the SAL mice with the LAL mice (their low- or non-aggressive counterpart) failed to reveal the violent dispositions of the former. Thus, the identification of violence is most appropriate when the test animal shows appreciable levels of aggression. The high-aggressive mice were shown to display a $15-40 \%$ aggression levels by both duration and frequency (Natarajan et al., 2009a).

\section{BIOLOGICAL VALIDATION OF VIOLENCE IN SAL MICE}

In the above section, we have described how SAL mice are behaviorally violent. However, we require not only behavioral characterization but also evidence from several other disciplines to support the construct validity of violence in the SAL mice. Below we compare specific findings on violence in the SAL mice with other rodent models. In particular, we consider 5-HT neurochemistry, neural correlates of human violence and HPA-axis reactivity, given their pivotal role in understanding human violence in the last 3-4 decades (as described in Section 'Animal Models of Violence').

\section{5-HT Neurochemistry}

Brain 5-HT levels were assessed in these mice both when naïve and after repeated agonistic interactions. Under naïve, non-fighting conditions, low 5-HT levels were not a consistent feature of the high-aggressive lines (Caramaschi et al., 2008a; Natarajan et al., 2009c). After repeated agonistic encounters, however, the tissue levels of forebrain 5-HT and its metabolite were generally lower in the high-aggressive lines than in the non-aggressive lines (Lagerspetz et al., 1968; Olivier et al., 1990; Veenema et al., 2005). The lowest prefrontal cortical 5-HT levels were characteristic of SAL mice when their aggression levels were saturated to the highest limit (Caramaschi et al., 2008a). This finding is in line with the human data on violence as well as with the 5-HT data from the WTG rats (Section 'Animal Models of Violence').

However, the expected lowered 5-HIAA levels and 5-HT turnover (due to repeated agonistic interactions) were not restricted to SAL mice alone. Similar declines were also observed in the other mouse lines, regardless of their aggressive tendencies (Caramaschi et al., 2008a). This difference from the human data can be attributed to three possible reasons. First, regulation of intra/extracellular 5-HT levels is not straightforward and is often seen as an interplay between several mediating proteins and enzymes, including TPH (enzyme that synthesizes 5-HT), MAO (enzyme that degrades 5-HT), 5-HT receptors, SERT (5-HTT, transporter protein that helps in 5-HT uptake from extracellular to intracellular milieu) and vesicular-matrix-associated transporter (VMAT, transporter protein that helps in sequestering $5-\mathrm{HT}$ in vesicles within the 5-HT neurons). It is possible that one or more of these players are differentially regulated, which might mask the otherwise violence-related hypo-serotonergic condition. The functional activities of these serotonergic candidates have just begun to be assessed for their likely role as neurochemical correlates of violence in the SAL mice (e.g., 5- $\mathrm{HT}_{1 \mathrm{~A}}, 5-\mathrm{HTT}, \mathrm{TPH}, \mathrm{MAO}$ ). An enhanced sensitivity of the $5-\mathrm{HT}_{1 \mathrm{~A}}$ autoreceptor seems to be one of the plausible causative mechanisms of maladaptive aggression (Caramaschi et al., 2007). The low serotonin levels in SAL mice are associated with enhanced sensitivity of the presynaptic and postsynaptic $5-\mathrm{HT}_{1 \mathrm{~A}}$ receptor and its expression in cortico-limbic structures (Korte et al., 1996; van der Vegt et al., 2001; Feldker et al., 2003; Veenema et al., 2005; Caramaschi et al., 2007). The enhanced $5-\mathrm{HT}_{1 \mathrm{~A}}$ receptor functionality may result in inhibited tonic release of 5 -HT. The consequence is probably an impaired serotonergic neuromodulation in key areas of behavioral inhibition control, such as the prefrontal cortex, leading to impulsivity. Secondly, CSF 5-HIAA levels, measured in humans and other primates, indicate the leftovers in the extracellular compartments, and are not directly comparable to the 5-HIAA levels or 5-HT turnover in the intracellular compartment of cortical neurons measured in mice and rats; thus posing a methodological challenge. Finally, certain environment/experience effects can also contribute to specifically lowering 5-HIAA levels (as seen in violent humans). This needs to be modeled in the SAL mice.

\section{Functional neuroanatomy}

The neural activation patterns of SAL mice associated with their exaggerated aggressive behavior have been scrutinized by Haller et al. (2001) using c-Fos immunocytochemistry. Agonistic encounters in 
the SAL mice were found to strongly activate the following brain regions: medial prefrontal cortex (infralimbic and prelimbic subdivisions), central amygdala, lateral/ventrolateral PAG, lateral septum, bed nucleus of stria terminalis and locus ceruleus.

Central amygdala activation was also observed in rats that were electrically stimulated at the HAA as well as ADxR rats (Haller et al., 2006). Adrenalectomized rats showed an additional activation of the paraventricular nucleus of the hypothalamus (involved in the control of the HPA axis) when compared to controls (Haller et al., 2005). Activation of the lateral/ventrolateral PAG and bed nucleus of stria terminalis has been observed during predatory aggression in cats. Predatory attack behavior or quiet attack (Wasman and Flynn, 1962), elicited by electric stimulation of the lateral hypothalamus/midbrain, led to strong bites typically at the back of the victim's neck (Wasman and Flynn, 1962; Flynn, 1976). The cat was often seen to lunge at the rat, striking it and placing a paw on it to position the victim, as well as positioning itself to bite the rat. The cat's pupils were usually dilated and moderate piloerection was observed. Vocalization and initial stalking of the prey were absent. As described earlier, predatory attack behavior in animals seems to overlap with human psychopathy where it is not sympathetically mediated (Meloy, 1988).

In addition to these brain areas, the medial amygdala was also activated in the SAL mice, which is the case during affective aggression in cats. Classic rage response/defensive rage behavior was elicited due to activation of the medial hypothalamus, ventral tegmentum, stria terminalis, and PAG in the cat (Siegel, 2004). The associated changes include sympathetic responses, namely an increase in heart rate and blood pressure, and behavioral responses such as hissing, retraction of the lips, laying back of the ears, arching of the back and marked piloerection (Magoun et al., 1937; Ranson and Magoun, 1939; Hess and Akert, 1955; Hunsperger, 1956, 1959, 1969; Layhausen, 1979).

The SAL mice thus seem to show neurobiological activation typical of both reactive and predatory/instrumental aggression, as seen in anti-socially disordered patients (Haller et al., 2005). Brain areas typical of territorial aggression, such as the dorsolateral PAG and lateral septum, were not activated in the SAL mice, suggesting a lack of territorial aggression in this model. Further investigations are required to resolve the neurobiological correlates in SAL mice pertinent to either instrumental or reactive violence. Comparative studies with TA and NC900 mouse models might offer this possibility.

\section{Stress physiology}

From an endocrine/physiological perspective, violence has been identified predominantly as either the reactive, hostile, emotional aggression or the instrumental or cold-blooded aggression as described in Section 'Animal Models of Violence'. While the former is consequential upon high stress reactivity in the sympatho-adrenomedullary system and/or in the HPA axis (anger and high emotional response), the latter is observed without any emotional arousal.

In line with the above findings, Caramaschi et al. (2008b) have shown a low resting heart rate in the SAL mice compared to TA or NC900, suggesting an imbalance in sympathetic/parasympathetic cardiovascular regulation shifted toward the low sympathetic or high parasympathetic (or both). In addition, the SAL mice showed a hyporesponsive HPA axis in comparison with the LAL mice (Veenema et al., 2003a). The response of the main rodent glucocorticoid hormone, corticosterone, to ACTH was significantly lower in SAL than in LAL mice. Chronic psychosocial stress induced long-lasting corticosterone increase in LAL mice compared to SAL mice. The dark-phase-related rise in corticosterone was also found to be less marked in SAL than in LAL mice (Veenema et al., 2003b). A similar observation was made with the ADxR rats, which increased their corticosterone levels by less than a half when under social stress. These rats were thus shown to display autonomic hypoarousal in addition to attacking the vulnerable parts of the opponent's body, as described earlier. They also showed social deficits in the social interaction test, similar to SAL mice (Figure 2, left half). This observation did not appear to result from a general increase in anxiety, as the rats failed to show signs of anxiety in other tests (elevated plus-maze and light/dark tests, Haller et al., 2005). Thus, the SAL mice can be considered to be stress hypo-reactive, like the $\mathrm{ADxR}$ rats with respect to heart rate and glucocorticoid production (Haller et al., 2001; Veenema et al., 2003a,b).

\section{DOES ANIMAL VIOLENCE TRANSLATE TO HUMAN VIOLENCE?}

In the previous section, we attempted to delineate violence from adaptive aggression in mice and assess its significance in various rodent models that are currently available. As a logical follow-up, one would like to confirm the validity of SAL violence as a model of human violence. Sluyter et al. (2003) envisaged SAL mice as a potentially valid model of human anti-social behavior, based on a number of measures including predisposition to alcohol, litter size and personality. A comparison of these rodent models is presented in relation to human violence in Table 1. Considering the behavioral criteria of violence outlined in Section 'Behavioral Sequence Leading to Aggression or Violence', we may conclude that the SAL model has a considerable degree of face validity to human violence. For instance, a lack of sensory processing (as described in Section 'Violence Versus Aggression - Operational Definitions' under pre-escalatory behaviors) has been attributed to a deficiency in processing negative stimuli (specifically sad or fearful facial expressions or vocals) in human subjects with psychopathy and its dispositions (Sommer et al., 2006). Individuals who frequently engage in anti-social behavior using instrumental aggression have been shown to display a reduced sympathetic baseline tone and low HPA axis tone and activation (Virkkunen, 1985; Raine et al., 1990, 2000; Scarpa and Raine, 1997; Raine, 2002a,b; Popma et al., 2006). Violent offenders with an abusive history have also been shown to mistreat animals in their early childhood, suggestive of context independency (Agnew, 1998). We attribute this to a combination of consistent harm-oriented behaviors with low attack latencies and context independency, alike in both humans and SAL mice alike. Considering the criteria of construct validity, it seems that the SAL model reflects the neurobiological and physiological characteristics of instrumental violence in humans. This holds in particular for the low 5-HT levels, low basal heart rates and low glucocorticoid responses in the SAL mice (Section 'SAL Mice as an Animal Model for Violence'). In view of this, we would argue that understanding the etiology 
Table 1 | Similarities between human violence and potential rodent models of aggressive behavior from multiple disciplines. The potential models compared include SAL mice, wild-type Groningen (WTG) rats, adrenalectomized (ADxR) glucocorticoid-deficient rats and instigation/frustration induced aggression and alcohol-heightened aggression (AHA) in CFW mice.

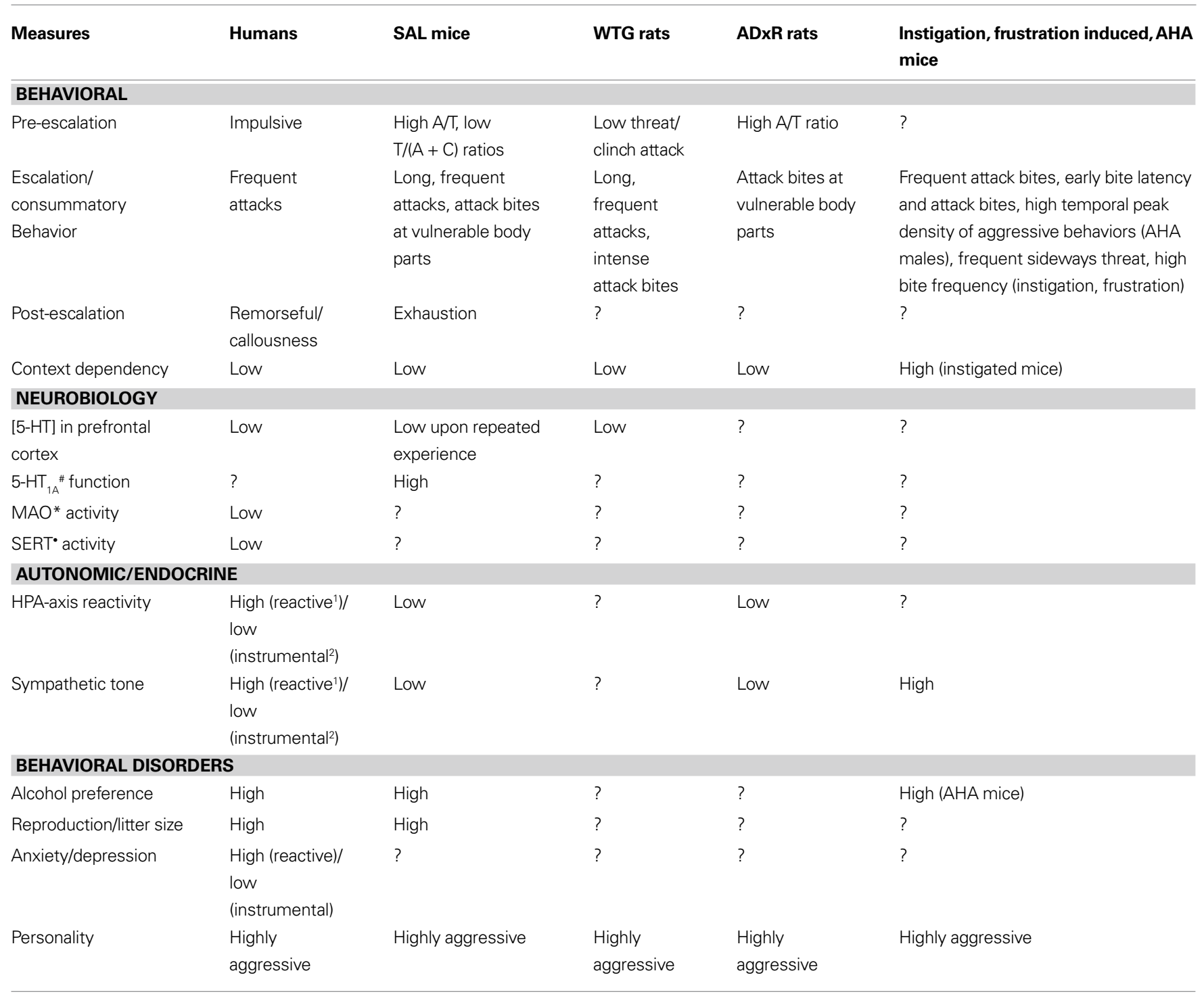

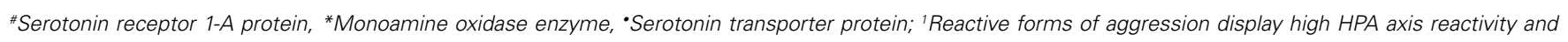
sympathetic tone while ${ }^{2}$ instrumental forms of aggression display relatively low HPA axis and sympathetic tone.

of violence, its prevention and treatment might profit from a mutual scientific exchange between human and rodent studies of aggression and violence in general.

\section{GENERAL CONCLUSIONS}

Through a comparative behavioral analysis of agonistic behaviors in the high-aggressive mouse lines SAL, TA and NC900, we have now identified an operational definition for violence. Differences between violence and adaptive aggression are qualitative, as established unanimously by studies using these rodents. The TA and NC900 lines are 'hyper-aggressive' strains that have proven useful as behavioral controls in the identification of the deviant forms of aggressive behavior in SAL mice. This comparison becomes especially important given the lack of similar behavioral features in toto in other rodent models. We therefore conclude that the SAL mice can be considered a reasonably valid animal model for human violence based on extensive similarities in the underlying behavioral and physiological symptomatology, etiology and putative neurobiological mechanisms.

\section{ACKNOWLEDGMENTS}

The authors thank Dr Sietse de Boer, Prof Jaap Koolhaas, Dr Tim Fawcett, the reviewers and Prof. Carmen Sandi for help in preparing this manuscript. 


\section{REFERENCES}

Agnew, R. (1998). The causes of animal abuse: a social-psychological analysis. Theor. Criminol. 2, 177-209.

Ainsworth, M., Blehar, M., Waters, E., and Wall,S. (1978). Patterns of Attachment. Hillsdale, NJ, Erlbaum.

Albert, D. J., Walsh, M. L., and White, R. (1985). Mouse killing induced by para-chlorophenylalanine injections or septal lesions but not olfactory bulb lesions is similar to that of fooddeprived spontaneous killers. Behav. Neurosci. 99, 546-554.

Anderson, C. A., and Ford, C. M. (1986). Affect of the game player: short-term effects of highly and mildly aggressive video games. Pers. Soc. Psychol. Bull. 12, 390-401.

Andrade, M. L., Kamal, K. B. H., and Brain, P. F. (1989). Effects of positive and negative fighting experiences on behaviour in adult male mice. In House Mouse Aggression, P. F. Brain, D. Mainardi and S. Parmigiani, eds (Chur, Switzerland, Harwood Academic Publishers).

Archer, J. (1988). The Behavioral Biology of Aggression. New York, Cambridge University Press.

Archer, J., and Huntingford, F. (1994). Game theory models and escalation of animal fights. In The Dynamics of Aggression, M. Potegal and J. F. Knutson, eds (Hillsdale, NJ, Lawrence Erlbaum Associates), pp. 3-31.

Arnone, M., and Dantzer, R. (1980). Does frustration induce aggression in pigs? Appl. Anim. Ethol. 6, 351-362.

Asberg, M., Traskman, L., and Thoren, P. (1976). 5-HIAA in the cerebrospinal fluid of the rat: measurement and use as an index of functionally active serotonin. Life Sci. 40, 2253-2260.

Aureli, F., Preston, S. D., and de Waal, F. B. M. (1999). Heart rate responses to social interactions in free-moving rhesus macaques: a pilot study. J. Comp. Psychol. 113, 59-65.

Azrin, N. H., Hutchinson, R. R. and Hake, D. F. (1966). Extinction-induced aggression. J. Exp. Anal. Behav. 9, 191-204.

Barnett, S. A., and Smart, J. L. (1975). The movement of wild and domestic house mice in an artificial environment. Behav. Biol. 15, 85-93.

Bell, C., Abrams, J., and Nutt, D. (2001). The functions of freezing in the social interactions of juvenile high- and low-aggressive mice. Physiol. Behav. 80, 57-67.

Benus, R. F., Bohus, B., Koolhaas, J. M, and van Oortmersson, G. A. (1991). Heritable variation for aggression as a reflection of individual coping strategies. Experientia 47, 1008-1019.

Berkowitz, L. (1984). Some effects of thoughts on anti- and prosocial influences of media events: A cognitive-neoassociation analysis. Psychol. Bull. 95, 410-427.

Berkowitz, L. (1989). Frustration-aggression hypothesis: examination and reformulation. Psychol. Bull. 106 , 59-73.

Berkowitz, L. (1993). Aggression: Its Causes, Consequences and Control. New York, McGraw-Hill.

Berman, M. E., and Coccaro, E. F. (1998). Neurobiologic correlates of violence: relevance to criminal responsibility. Behav. Sci. Law 16, 303-318.

Bjork, J. M., Dougherty, D. M., Moeller, F. G., and Swann, A. C. (2000) Differential behavioral effects of plasma tryptophan depletion and loading in aggressive and non-aggressive men. Neuropsychopharmacology 22, 357-369.

Blonigen, D. M., and Krueger, R. F. (2006) Human quantitative genetics of aggression. In Biology of Aggression, R. Nelson, ed. (New York, Oxford University Press).

Boccia, M. L., Reite, M., and Laudenslager, M. L. (1989). On the physiology of grooming in a pigtail macaque. Physiol. Behav. 45, 667-670.

Bowlby, J. (1969). Attachment and Loss, Vol. 1. Attachment. New York, Basic Books.

Bowlby, J. (1988). A secure base: parent-child attachment and healthy human development. New York, Basic Books.

Brain, P. F. (1989). The adaptiveness of house mouse aggression. In House Mouse Aggression. P. F. Brain, D. Mainardi and S. Parmigiani, eds (Chur, Switzerland, Harwood Academic Publishers).

Brecklin, L. R., and Ullman, S. E. (2002) The roles of victim and offender alcohol use in sexual assaults: results from the national violence against women survey. J. Stud. Alcohol 63, 57-63.

Breese, G. R., and Cooper, B. R. (1975). Behavioral and biochemical interactions of 5,7-dihyroxy-tryptamine with various drugs when administered intracisternally to adult and developing rats. Brain Res. 98, 517-527.

Brown, G. L., Goodwin, F. K., Ballenger, J. C., Goyer, P. F., and Major, L. F. (1979). Aggression in humans correlates with cerebrospinal fluid amine metabolites. Psychiatr. Res. 1, 131-139.

Brunner, H. G., Nelen, M., Breakefield, X O., Ropers, H. H., and van Oost, B. A (1993). Abnormal behavior associated with a point mutation in the structural gene for monoamine oxidase A. Science 262, 578-580.

Burns, R. D. (1968). The role of agonistic behavior in regulation of density in Uinta ground squirrels, Citellus armatus. M.S. thesis, Utah State University.

Bushman, B. J. (1997). Effects of alcohol on human aggression: validity of proposed mechanisms. In Recent Developments in Alcoholism, M. Galanter, ed. (New York, Plenum Press), pp. 227-244.

Bushman, B. J., and Cooper, H. M. (1990) Effects of alcohol on human aggression: an integrative research view. Psychol. Bull. 107, 341-354.

Busser, J.,Zweep,A., and van Oortmerssen, G. A. (1974). Variability in the aggressive behavior of Mus musculus domesticus, its possible role in population structure. In The Genetics of Behavior J. H. F. Van Abeelen, ed. (Amsterdam, North-Holland Publishing Company). pp. 185-199.

Calhoun, J.B. (1948). Mortality and movement of brown rats Rattus norvegicus in artificially supersaturated populations. J. Wildl. Manage. 12, 167-172.

Caramaschi, D., de Boer, S. F., and Koolhaas, J. M. (2007). Differential role of the 5-HT1A receptor in aggressive and non-aggressive mice: an across-strain comparison. Physiol. Behav. 90, 590-601.

Caramaschi, D., de Boer, S. F., de Vries, H., and Koolhaas, J. M. (2008a). Development of violence in mice through repeated victory along with changes in prefrontal cortex neurochemistry. Behav. Brain Res. 189, 263-272.

Caramaschi, D., de Boer, S. F., and Koolhaas, J. M. (2008b). Is hyperaggressiveness associated with physiological hypoarousal? A comparative study on mouse lines selected for high and low aggressiveness. Physiol. Behav. 95, 591-598.

Caras, R. (1969). In defense of the Grizzly. Audubon 71, 52-55.

Carpenter, C. R. (1934). A field study of the behavior and social relations of howling monkeys. Comp. Psychol. Monogr. 10, 1-168.

Carpenter, C. R. (1942). Societies of monkeys and apes. Biol. Symp. 8 177-204.

Carrington, R. (1958). Elephants. A Short Account of their Natural History, Evolution and Influence on Mankind. New York, Basic Books.

Caspi, A., McClay, J., Moffitt, T. E., Mill, J., Martin, J., Craig, I. W., Taylor, A. Poulton, R. (2002). Role of genotype in the cycle of violence in maltreated children. Science 297, 851-854.

Chamberlain, B., Ervin, F. R., Pihl, R. O. and Young, S. N. (1987). The effect of raising or lowering tryptophan levels on aggression in vervet monkeys. Pharmacol. Biochem. Behav. 28, 503-510.
Cherek, D. R., and Pickens, R. (1970). Schedule-induced aggression as a function of fixed-ratio value. J. Exp. Anal. Behav. 14, 309-311.

Cleare, A. J., and Bond, A. J. (1995). The effect of tryptophan deletion and enhancement on subjective and behavioral aggression in normal male subjects. Psychopharmacology (Berl.) 118, 72-81.

Coburn, C. A. (1922). Heredity of wildness and savageness in mice. Behav. Monogr. 4, 1-71.

Connor, J.L. (1974). Waning and recovery of conspecific aggression in the house mouse (Mus musculus L). J. Comp. Physiol. Psychol. 87, 215-227.

Corbett, J. (1957). Man-eaters of India New York, Oxford University Press.

Couppis, M. H., and Kennedy, C. H. (2008). The rewarding effect of aggression is reduced by nucleus accumbens dopamine receptor antagonism in mice. Psychopharmacology (Berl.) 197, 449-456.

Craig, I. W. (2007). The importance of stress and genetic variation in human aggression. Bioassays 29, 227-236.

Darling, F. F. (1937). A Herd of Red Deer. Oxford, Oxford University Press.

Dawkins, R., and Krebs, J. R. (1978). Animal signals: information or manipulation? In Behavioral Ecology: An Evolutionary Approach, R. Krebs and N. B. Davies, eds (Oxford, Blackwell Press), pp. 282-309.

Deater-Deckard, K., and Plomin, R. (1999). An adoption study of the etiology of teacher and parent reports of externalizing behavior problems in middle childhood. Child Dev. 70, 144-154.

de Boer, S. F., Caramaschi, D., Natarajan, D., and Koolhaas, J. M. (2009). The vicious cycle towards violence: focus on the negative feedback mechanisms of brain serotonin neurotransmission. Front. Behav. Neurosci. 3:52. doi: 10.3389/neuro.08.052.2009.

de Boer,S. F., and Koolhaas, J.M. (2005). 5HT1A and 5-HT1B receptor agonists and aggression: a pharmacological challenge of the serotonin deficiency hypothesis. Eur. J. Pharmacol. 526 125-139.

de Boer, S. F., van der Vegt, B. J., and Koolhaas, J. M. (2003). Individual variation in aggression of feral rodent strains: a standard for the genetics of aggression and violence? Behav. Genet 33, 485-501.

de Bruin, J.P.C. (1990). Orbital prefrontal cortex, dopamine and social agonistic behavior of male Long Evans rats. Aggress. Behav. 16, 231-248.

de Bruin, J. P. C., van Oyen, H. G. M., and van de Poll, N. (1983). Behavioural changes following lesions of the 
orbital prefrontal cortex in male rats. 10, 209-232.

de Waal, F. (2005). Our Inner Ape. New York, Riverhead/Penguin Press.

Dill, J. C., and Anderson, C. A. (1995). Effects of frustration justification on hostile aggression. Aggress. Behav. 21, 359-369.

Dill, K. E., and Dill, J. C. (1998). Video game violence: a review of the empirical literature. Aggress. Violent Behav. 3, 407-428.

Dollard, J., Doob, L. W., and Miller, N. E. (1939). Frustration and Aggression. New Haven, Yale University Press.

Drescher, V. M., Gantt, W. H., and Whitehead, W. E. (1980). Heart rate response to touch. Psychosom. Med. $42,559-565$.

Drescher, V. M., Hayhurst, V., Whitehead, W. E., and Joseph, J. A. (1982). The effects of tactile stimulation on pulse rate and blood pressure. Biol. Psychiatry 17, 1347-1352.

Ebert, P. D. (1976). Agonistic behavior in wild and inbred Mus musculus. Behav. Biol. 18, 291-294.

Enserink, M. (2000). Searching for the mark of Cain. Science 289, 575-579.

Farrell, G. A., and Dares, G. (1996). Seclusion or solitary confinement: therapeutic or punitive treatment? Aust. N. Z. J. Ment. Health Nurs. 5, 171-179.

Feh, C., and de Mazieres, J. (1993). Grooming at a preferred site reduces heart rate in horses. Anim. Behav. 46, 1191-1194.

Feldker, D. E., Datson, N. A., Veenema, A. H., Meulmeester, E., de Kloet, E. R., and Vreugdenhil, E. (2003). Serial analysis of gene expression predicts structural differences in hippocampus of long attack latency and short attack latency mice. Eur. J. Neurosci. 17, 379-387.

Fish, E. W., De Bold, J. F., and Miczek, K. A. (2005). Escalated aggression as a reward: corticosterone and GABA(A) receptor positive modulators in mice. Psychopharmacology (Berl). 182, 116-127.

Fish, E. W., Faccidomo, S., and Miczek, K. A. (1999). Aggression heightened by alcohol or social instigation in mice: reduction by the 5-HT(1B) receptor agonist CP94,253. Psychopharmacology (Berl.) 146, 391-399.

Flynn, J. P. (1976). Neural basis of threat and attack. In Biological Foundations of Psychiatry. R. G. Grenell and S. Gabay, eds (New York, Raven Press).

Fox, A., and Spector, P.E. (1999). A model of work frustration-aggression. J. Organ. Behav. 20, 915-931.

Garattini, S., Giacalone, E., and Valzelli, L. (1967). Isolation, aggressiveness and brain 5-hydroxytryptamine turnover. J. Pharm. Pharmacol. 19, 338-339.

Gibbons, J. L., Barr, G. A., Bridger, W. H., and Fryer Leibowitz, S. (1978). Effects of para-chlorophenylalanine and 5hydroxy tryptophan on mouse killing behavior in killer rats. Pharmacol. Biochem. Behav. 9, 91-98.

Gilbert, P. W. (1968). The shark: barbarian and benefactor. Bioscience 18, 946-950.

Greenfield, L. A., and Henneberg, M. A. (2000). Alcohol, crime and the criminal justice system. In Commissioned Paper for the Alcohol Policy XII Conference, Alcohol and Crime, Research and Practice for Prevention, Washington, DC.

Guo, G., Roettger, M.E., Shih, J. C. (2007). Contributions of the DAT1 and DRD2 genes to serious and violent delinquency among adolescents and young adults. Hum. Genet. 121, 125-136.

Halasz, J., Liposits, Z., Meelis, W., Kruk, M. R., and Haller, J. (2002). Hypothalamic attack area-mediated activation of the forebrain in aggression. Neuroreport 13, 1267-1270.

Haller,J., Halasz,J., Mikics, E., and Kruk,M. R. (2004). Chronic glucocorticoid deficiency-induced abnormal aggression, autonomic hyperarousal, and social deficits in rats. J. Neuroendocrinol. 16 , 550-557.

Haller, J. and Kruk, M. R. (2006). Normal and abnormal aggression: human disorders and novel laboratory models. Neurosci. Biobehav. Rev. 30, 292-303.

Haller, J., Mickics, E., Halasz, J., and Toth, M.. (2005). Mechanisms differentiating normal from abnormal aggression: glucocorticoids and serotonin. Eur. J. Pharmacol. 526, 89-100.

Haller, J., Toth, M., Halasz, J., and de Boer, S. F. (2006). Patterns of violent aggression-induced brain c-fos expression in male mice selected for aggressiveness. Physiol. Behav. 88, 173-182.

Haller, J., van de Schraaf, J., and Kruk, M. R. (2001). Deviant forms of aggression in glucocorticoid hyporeactive rats: a model for 'pathological' aggression? J. Neuroendocrinol. 13, 102-107.

Harlow, H. F., Harlow, M. K. and Soumi, S. J. (1971). From thought to therapy: lessons from a primate laboratory. Am. Sci. 59, 538-549.

Harlow, J. M. (1848). Passage of an iron rod through the head. Boston Med. Surg. J. 39, 389-393.

Harlow, J. M. (1868). Recovery from the passage of an iron bar through the head. Publ. Mass. Med. Soc. 2, 327-346.

Hennessy, M. B., Voith, V. L., Mazzei, S. J., Buttram, J., Miller, D. D., and Linden, F. (2001). Behavior and cortisol levels of dogs in a public animal shelter and an exploration of the ability of these measures to predict problem behavior after adoption. Appl. Anim. Behav. Sci. $73,217-233$.

Herrenkohl, T.I., McMorris, B. J., catalano, R. F., Abbott, R. D., Hemphill, S. A., and Toumbourou, J.W. (2007). Risk factors for violence and relational aggression in adolescence. J. Interpers. Violence 22, 386-405.

Hess, W. R., and Akert, K. (1955). Experimental data on role of hypothalamus in mechanism of emotional behavior. Arch. Neurol. Psychiatry 73 , 127-129.

Higley, J. D., Suomi, S. J., and Linnoila, M. (1991). CSF monoamine metabolite concentrations vary according to age, rearing and sex, and are influenced by the stressor of social separation in rhesus monkeys. Psychopharmacology 103, 551-556.

Hole, K., Johnson, G. E., and Berge, O. G. (1977). 5,7-Dihydroxytryptamine lesions of the ascending 5-hydroxytryptamine pathways: habituation, motor activity and agonistic behavior. Pharmacol. Biochem. Behav. 30 439-446.

Hsu, Y., Earley, R. L., and Wolf, L. L. (2006). Modulation of aggressive behavior by fighting experience: mechanisms and contest outcomes. Biol. Rev. Camb. Philos. Soc. 81, 33-74.

Hunsperger,R.W.(1956).Affektreactionen auf elektrische Reizung im Hirnstamm der Katze. Helv. Physiol. Acta. 14, 70-92.

Hunsperger, R. W. (1959). Les representation centrales des reactions affectives dans le cerveau anterieur et dans le tronc cerebral. Neurochirurgie 5, 207-233.

Hunsperger, R.W. (1969). Die Asynchrone und Lokal umschriebene Reizwirkung von Mittelfrequenz-Dauerstromen im Hypothalamus der Katze. Exp. Brain Res. 9, 164-182.

Huntingford, F. A., and Turner, A. K. (1987). Animal Conflict. Cambridge, Cambridge University Press).

Ieni, J. R., and Thurmond, J. B. (1985). Maternal Aggression in mice: effects of treatments with PCPA, 5-HTP and 5-HT receptor agonists. Eur. J. Pharmacol. 111, 211-220.

Kantak,K.M.(1981).Facilitation of shockinduced fighting followed intraventricular 5,7-dihydroxytryptamine and 6-hydroxydopa. Psychopharmacology 74, 157-160.

Kantak, K. M., Hegstrand, L. R., and Eichelman, B. (1980a). Dietary tryptophan modulation and aggressive behavior in mice. Pharmacol. Biochem. Behav. 12, 675-679.

Kantak, K. M., Hegstrand, L. R., Whitman, J., and Eichelman, B. (1980b). Effects of dietary supplements and a tryptophan-free diet on aggressive behav- ior in rats. Pharmacol. Biochem. Behav. 12, 173-179.

Kantak, K. M., Hegstrand, L. R., and Eichelman, B. (1981). Dietary tryptophan reversal of septal lesion and 5,7-DHT lesion elicited shock-induced fighting. Pharmacol. Biochem. Behav. $15,343-350$.

Karavanich, C., and Atema, J. (1998). Individual recognition and memory recognition in lobster dominance. Anim. Behav. 56, 1553-1560.

Kariyawasam, S. H., Zaw, F., and Handley, S. L. (2002). Reduced salivary cortisol in children with comorbid attention deficit hyperactivity disorder and oppositional defiant disorder. Neuroendocrinol. Lett. 23, 45-48.

Keele, N. B. (2001). Phenytoin inhibits isolation-induced aggression specifically in rats with low serotonin. Neuroreport 12, 1107-1112.

Kendler, K. S., Gardner, C. O., and Prescott, C.A. (2003). Personality and the experience of environmental adversity. Psychol. Med. 33, 1193-1202.

Koolhaas, J. M. (1978). Hypothalamically induced intraspecific aggressive behavior in the rat. Exp. Brain Res. 32, 365-375.

Koolhaas, J. M., de Boer, S. F., and Buwalda, B. (2010). Neurobiology of offensive aggression. In Encyclopedia of Behavioral Neuroscience, G. Koob, M. le Moal and R. Thompson, eds (San Diego, Elsevier Press).

Korte, S. M., Meijer, O. C., de Kloet, E. R., Buwalda, B., Keijser, J., Sluyter, F., Van Oortmerssen G., and Bohus, B. (1996). Enhanced 5-HT1A receptor expression in forebrain regions of aggressive house mice. Brain Res. 736, 338-343.

Kraemer, G.W. (1992). A psychobiological theory of attachment. Behav. Brain Sci. $15,493-511$.

Krug, E. G., Dahlberg, L. L., Mercy, J. A., Zwi, A. B., and Lozano, R. (2002). World Report on Violence and Health. Geneva: World Health Organization.

Kruk, M. R. (1991). Ethology and pharmacology of hypothalamic aggression in the rat. Neurosci. Biobehav. Rev. 15, 524-538.

Kruk, M. R., van der Laan, C. E., van der Poel, A. M., van Erp, A. M. M., and Meelis, W. (1990). Strain differences in attack patterns elicited by electrical stimulation in the hypothalamus of male rats. Aggress. Behav. 16, 177-190.

Kruk, M. R., van der Poel, A. M., and de Vos-Frerichs, T. P. (1979). The induction of aggressive behaviour by electrical stimulation in the hypothalamus of male rats. Behaviour 70, 292-322.

Kudryatseva, N. N. (2000). Experimental approach to the study of learned aggression. Aggress. Behav. 26, 241-256. 
Kudryatseva, N. N., Bondar, N. P., and Alekseyenko, O. V. (2000). Behavioral correlates of aggression. Aggress. Behav. 26, 386-400.

Lagerspetz, K. (1961). Genetic and Social causes of aggressive behavior in mice. Scand. J. Psychol. 2, 167-173.

Lagerspetz, K. M., and Lagerspetz, K. Y. (1971). Changes in the aggressiveness of mice resulting from selective breeding, learning and social isolation. Scand. J. Psychol. 9, 157-160.

Lagerspetz, K.Y., Tirri, R., and Lagerspetz, K. M. (1968). Neurochemical and endocrinological studies of mice selectively bred for aggressiveness. Scand. J. Psychol. 9, 157-160.

Lammers, J.H. C. M., Kruk, M. R., Meelis, W., and van der Poel, A. M. (1988). Hypothalamic substrates for brain stimulation-induced patterns of locomotion and escape jumps in the rat. Brain Res. 449, 294-310.

Layhausen, P. (1979). Cat Behavior: The Predatory and Social Behavior of Domestic and Wild Cats. New York, Garland STPM Press.

Leary, M. R., Twenge, J. M., and Quinlivan, E. (2006). Interpersonal rejection as a determinant of anger and aggression. Pers. Soc. Psychol. Rev. 10, 111-132.

Lee, R., and Coccaro, E. F. (2001). The neuropsychopharmacology of criminality and aggression. Can. J. Psychiatry 46, 35-44.

Lewis, C.E. (1991). Neurochemical mechanisms of chronic anti-social behavior (psychopathy). A literature review. J. Nerv. Ment. Dis. 179, 720-727.

Linnoila, M., Virukkunen, M., Scheinin, M., Nuutila, A., Rimon, R., and Goodwin, F. K. (1983). Low cerebrospinal fluid 5-hydroxyindoleacetic acid concentration differentiates impulsive from non-impulsive violent behavior. Life Sci. 33, 2609-2614.

Linnoila, V. M., and Virukkunen, M. (1992). Aggression, suicidality and serotonin. J. Clin. Psychiatry 53, 46-51.

Lorenz, K. (1966). On Aggression. New York, Bantam Press.

Maas, J. W. (1962). Neurochemical differences between two strains of mice. Science 137, 621-622.

Maes, M., Cosyns, P., Meltzer, H. Y., De Meyer, J., and Peeters, D. (1993). Seasonality in violent suicide but not in non-violent suicide or homicide. Am. J. Pyschiatry 150, 1380-1385.

Magoun, H. W., Atlas, D., Ingersoll, E. H., Ranson, S.W. (1937).Associated facial, vocal and respiratory components of emotional expression: an experimental study. J. Neurol. Psychopathol. 17, 241-255.

Martin, S. E., and Bachman, R. (1997). The relationship of alcohol to injury in assault cases. In Recent Developments in Alcoholism, M. Galanter, ed. (New York, Plenum Press). pp. 42-56.

Mathews, L. H. (1964). Overt fighting in mammals. In The Natural History of Aggression, J. D. Carthy and F. J. Ebling, eds (New York, Academic Press).

McBurnett, K., Lahey, B. B., Rathouz, P. J., and Loeber, R. (2000). Low salivary cortisol and persistent aggression in boys referred for disruptive behavior. Arch. Gen. Psychiatry 57, 38-43.

McCloskey, M. S., Ben-Zeev, D., Lee, R., Berman, M. E., and Coccaro, E. F. (2009). Acute Tryptophan depletion and self-injurious behavior in aggressive patients and healthy volunteers. Psychopharmacology 203, 53-61.

McSweeney, F. K., and Swindell, S. (2002). Common processes may contribute to extinction and habituation. J. Gen. Psychol. 129, 364-400.

Meloy, J. R. (1988). The Psychopathic Mind: Origins, Dynamics and Treatment. Northvale, NJ, Jason Aronson, Inc.

Miczek, K. A., Altman, J. L., Appel, J. B., and Boggan, W. O. (1975). Parachlorophenylalanine, serotonin and killing behavior. Pharmacol. Biochem. Behav. 3, 355-361.

Miczek, K.A., Faccidomo, S., De Almeida, R. M., Bannai, M., Fish, E. W., and Debold, J. F. (2004). Escalated aggressive behavior: new pharmacotherapeutic approaches and opportunities. Ann. N. Y. Acad. Sci. 1036, 336-355.

Miczek, K. A., Fish, E. W., and De Bold, J. F. (2003). Neurosteroids, GABA receptors and escalated aggressive behavior. Horm. Behav. 44, 242-257.

Miczek, K. A., Fish, E. W., de Bold, J. F. and de Almeida, R. M. (2002). Social and neural determinants of aggressive behavior: pharmacotherapeutic targets at serotonin, dopamine and gamma-aminobutyric acid systems. Psychopharmacology (Berl.) 163, 434-458.

Miczek, K. A., Maxson, S. C., Fish, E. W., and Faccidomo, S. (2001). Aggressive behavioral phenotypes in mice. Behav. Brain Res. 125, 167-181.

Miczek, K. A., Weerts, E. M., Tornatzky, W., DeBold, J. F., and Vatne, T. M. (1992). Alcohol and 'Bursts' of aggressive behavior: ethological analysis of individual differences in rats. Psychopharmacology (Berl.) 107, 551-563.

Mineur, Y. S., Prasol, D. J., Belzung, C., and Crusio, W. E. (2003). Agonistic behavior and unpredictable chronic mild stress in mice. Behav. Genet. 33, 513-519.

Moffitt, T.E. (1993). Adolescence-limited and life-course-persistent antisocial behavior: a developmental taxonomy. Psychol. Rev. 100, 674-701.
Molla-Hosseini, C. (1985). Modulation of action of kainic acid on the behavior of rats by p-chlorophenylalanine and by gaba-mimetic drugs. Biochemical correlation between behavior and treatments. J. Pharmacol. 16, 299-312.

Murdoch, D., Pihl, R. O., and Ross, D. (1990). Alcohol and crimes of violence: present issues. Int. J. Addict. 25 , 1065-1081.

Myers, K. (1966). The effects of density on sociality and health in mammals. Proc. Ecol. Soc. Aust. 1, 40-64.

Nagin, D., and Tremblay, R. E. (1999). Trajectories of boys' physical aggression, opposition and hyperactivity on the path to physically violent and nonviolent juvenile delinquency. Child Dev. 70, 1186-1196.

Natarajan, D., de Vries, H., Saaltink, D. de Boer, S. F., and Koolhaas, J. M (2009a). Delineation of violence from functional aggression in mice: an ethological approach. Behav. Genet. 39, 73-90.

Natarajan, D., de Vries, H., de Boer, S. F. and Koolhaas, J. M. (2009b). Violent phenotype in SAL mice is inflexible and fixed in adulthood. Aggress. Behav. 35, 430-436.

Natarajan, D., de Boer, S. F., and Koolhaas, J.M. (2009c). Lack of differential sero tonin biosynthesis capacity in genetically selected low and high aggressive mice. Physiol. Behav. 98, 411-415.

Nelson, R. J., and Chiavegatto, S. (2001) Molecular basis of aggression. Trends Neurosci. 24, 713-719.

Nelson, R. J., and Trainor, B. C. (2007) Neural mechanisms of aggression. Nat. Rev. Neurosci. 8, 536-546.

Olivier, B., Mos, J., Tulp, M., Schipper, J. Den Daas, S. J., and van Oortmerssen G.A. (1990).Serotonergic involvement in aggressive behavior in animals. In Violence and Suicidality: Perspectives in Clinical and Psychological Research, H. M. van Praag, R. Plutchik and A. Apter, eds (New York, Brunner/Mazel), pp. 79-84.

Pajer, K., Gardner, W., Rubin, R. T., Perel J., and Neal, S. (2001). Decreased cortisol levels in adolescent girls with conduct disorder. Arch. Gen. Psychiatry 58 297-302.

Pavlov, I. P. (1927). Conditioned Reflexes London, Oxford University Press (translated by G. V. Anrep).

Paxinos, G., Burt, J., Atrens, D. M. and Jackson, D. M. (1977). 5Hydroxytryptamine depletion with para-chlorophenylalanine: effects on eating, drinking, irritability, muricide and copulation. Pharmacol. Biochem. Behav. 6, 439-447.

Pihl, R. O., Young, S. N., Harden, P., Plotnick, S., Chamberlain, B., and Ervin, F. R. (1995). Acute effect of altered tryptophan levels and alcohol on aggression in normal human males. Psychopharmacology 119, 353-360.

Popma, A., Jansen, L. M., Vermeiren, R., Steiner, H., Raine, A., Van Goozen, S. H., van Engeland, H., and Doreleijers, T. A. (2006). Hypothalamus pituitary adrenal axis and autonomic activity during stress in delinquent male adolescents and controls. Psychoneuroendocrinology 31, 948-957.

Potegal, M. (1992). Time course of aggressive arousal in female hamsters and male rats. Behav. Neural Biol. 58, 120-124.

Potegal, M., and Einon, D. (1989). Aggressive behaviors in adult rats deprived of playfighting experiences as juveniles. Dev. Psychobiol. 22, 159-172.

Potegal, M., Huhman, K., Moore, T., and Meyerhoff, K. (1993). Conditioned defeat in the Syrian golden hamster (Mesocricetus auratus). Behav. Neural Biol. 60, 93-102.

Pottinger, T. G., and Carrick, T. R. (2001). Stress responsiveness affects dominant-subordinate relationships in rainbow trout. Horm. Behav. 40 419-427.

Preuschoft, S. (1995). 'Laughter' and 'Smiling' in Barbary Macaques: An Evolutionary Perspective. Utrecht, University of Utrecht.

Preuschoft, S., and van Schaik, P. (2000). Dominance and communication. Conflict management in various social settings. In Natural Conflict Resolution, F. Aureli and F. de Waal, eds (Berkeley, University of California Press), pp. 77-105.

Raine, A. (2002a). Annotation: the role of prefrontal deficits, low autonomic arousal, and early health factors in the development of antisocial and aggressive behavior in children. J. Child. Psychol. Psychiatry 43, 417-434.

Raine, A. (2002b). Biosocial studies of antisocial and violent behavior in children and adults: a review. J. Abnorm. Child. Psychol. 30, 311-326.

Raine, A., Lencz, T., Bihrle, S., LaCasse, L., and Colletti, P. (2000). Reduced prefrontal gray matter volume and reduced autonomic activity in antisocial personality disorder. Arch. Gen. Psychiatry 57, 119-127.

Raine, A., Venables, P. H., and Williams, M. (1990). Autonomic orienting responses in 15 year-old male subjects and criminal behavior at age 24. Am. J. Psychiatry 147, 933-937.

Ranson, S. W., and Magoun, H.W. (1939). The hypothalamus. Ergeb. Physiol. 41, 56-163.

Reif,A., Jacob, C. P., Rujescu, D., Herterich, S., Lang, S., Gutknecht, L., Baehne, C. G., Strobel,A., Freitag, C. M., Giegling, I., Romanos, M., Hartmann,A., Rosler, 
M., Renner, T. J., Fallgatter, A. J., Retz, W., Ehlis, A. C., and Lesch, K. P. (2009). Influence of functional variant of neuronal nitric oxide synthase on impulsive behaviors in humans. Arch. Gen. Psychiatry 66, 41-50.

Retz, W., and Rosler, M. (2009). The relation of $\mathrm{ADHD}$ and violent aggression: what can we learn from epidemiological and genetic studies? Int. J. Law Psychiatry 32, 235-243.

Sandnabba, N. K. (1986). Effects of selective breeding for high and low aggressiveness and of fighting experience on odor discrimination in mice. Aggress. Behav. 12, 359-366.

Scarpa, A. and Raine, A. (1997). Psychophysiology of anger and violent behavior. Psychiatr. Clin. North Am. 20, 375-394.

Schaller, G. B. (1963). The mountain gorilla: ecology and behaviour. Chicago, University of Chicago Press.

Scott, J. P. (1958). Aggression. Chicago, University of Chicago Press.

Sewell, R. G., Gallus, J. A., Gault, F. P., and Cleary, J. P. (1982). P-chlorophenylalanine effects on shock-induced attack and pressing responses in rats. Pharmacol. Biochem. Behav. 17, 945-950.

Sharps, P. W., Campbell, J., Campbell, D., Gary, F., and Webster, D. (2001). The role of alcohol use in intimate partner femicide. Am. J. Addict. 10, 122-135.

Shinar, D. (1998). Aggressive driving: the contribution of the drivers and the situation. Transp. Res. F Traffic Psychol. Behav. 1, 137-160.

Siegel, A. (2004). The Neurobiology of Aggression and Rage. Boca Raton, FL, CRC Press

Siegel, A., Edinger, H., and Dotto, M. (1975). Effects of electrical stimulation of the lateral aspect of the pre-frontal cortex upon attack behaviors in cats. Brain Res. 127, 185-190.

Siegel, A., Edinger, H., and Lowenthal, H. (1974). Effects of electrical stimulation of the medial aspect of the pre-frontal cortex upon attack behavior in cats. Brain Res. 66, 467-479.

Siegel, A., Roeling, T. A., Gregg, T. R., and Kruk,M.R.(1999).Neuropharmacology of brain-stimulation-evoked aggression. Neurosci. Biobehav. Rev. 23, 359-389.

Siegel, A., and Victoroff, J. (2009). Understanding human aggression: new insights from neuroscience. Int. J. Law Psychiatry 32, 209-215.
Siever, L., and Trestman, R. L. (1993). The serotonin system and aggressive personality disorder. Int. Clin. Psychopharmacol. 8(Suppl. 2), 33-39.

Singleton, G. R., and Hay, D. A. (1982). A genetic study of male social aggression in wild and laboratory mice. Behav. Genet. 12, 435-448.

Sluyter, F., Arsenault, L., Moffitt, T. E., Veenema, A. H., de Boer, S., and Koolhaas, J. M. (2003). Toward an animal model for anti-social behavior: parallels between mice and humans. Behav. Genet. 33, 563-574.

Smith, M. J., and Parker, G. A. (1976). The logic of asymmetric contests. Behaviour 24, 159-75.

Sommer, M., Hajak, G., Dohnel, K. Schwerdtner, J., Meinhardt, J., and Muller, J. L. (2006). Integration of emotion and cognition in patients with psychopathy. Prog. Brain Res. $156,457-466$.

Southwick, C. H. (1955). The population dynamics of confined house mice with unlimited food. Ecology 36, 212-225.

Southwick, C. H. (1970). Conflict and violence in animal societies. In Animal Aggression. Selected Readings, C. H. Southwick, ed. (New York, van Nostrand Reinhold Company), pp. $1-13$.

Stokes, A. W. (1969). Aggressive Man and Aggressive Beast. In 39th Honor Faculty Lecture (Logan, Utah State University), pp. 1-22.

Suomi, S. J. (2003). Gene-environment interactions and the neurobiology of social conflict. Ann. N. Y. Acad. Sci. 1008, 132-139.

Thompson, T. (1964). Visual reinforcement in fighting cocks. J. Exp. Anal. Behav. 7, 45-49.

Thompson, T., and Bloom, W. (1966). Aggressive behavior and extinction-induced response rate increase. Psychon. Sci. 5, 335-336.

Utsurikawa, N. (1917). Temperamental differences between outbred and inbred strains of the albino rat. $J$. Anim. Behav. 7, 111-129.

Valzelli, L., Bernasconi, S., and Garattini, S. (1981). P-Chlorophenylalanineinduced muricidal aggression in male and female laboratory rats. Neuropsychobiology 7, 315-320.

van der Poel, A. M., Olivier, B., Mos, J., Kruk, M. R., Meelis, W., and van Aken, J. H. (1982). Anti-aggressive effect of a new phenylpiperazine compound (DU27716) on hypothalamically induced behavioral activities. Pharmacol. Biochem. Behav. 17, 147-153.

van der Vegt, B., de Boer, S. F., Buwalda, B., de Ruiter, A. J., de Jong, J. G., and Koolhaas, J. M. (2001). Enhanced sensitivity of postsynaptic serotonin-1A receptors in rats and mice with high trait aggression. Physiol. Behav. 74 205-211.

van der Vegt, B. J., Lieuwes, N., Cremers, T. I., de Boer, S. F., and Koolhaas, J. M. (2003). Cerebrospinal fluid monoamine and metabolite concentrations and aggression in rats. Horm. Behav. 44 199-208.

van Oortmerssen, G. A., and Bakker, T. C M. (1981).Artificial selection for short and long attack latencies in wild $M u$ s musculus domesticus. Behav. Genet. 6 , 291-304.

van Oortmerssen, G. A., and Busser, J. (1987). Studies in wild house mice 3: disruptive selection on aggression as a possible force in evolution. In House Mouse Aggression, P. F. Brain D. Mainardi and S. Parmigiani, eds (Chur, Switzerland, Harwood Academic Publishers).

Veenema, A. H. (2009). Early life stress, the development of aggression and neuroendocrine and neurobiological correlates: what can we learn from animal models? Front. Neuroendocrinol. 30, 497-518.

Veenema, A. H., Cremers, T. I., Jongsma, M. E., Steenbergen, P. J., de Boer, S. F., and Koolhaas, J. M. (2005). Differences in the effects of 5-HT(1A) receptor agonists on forced swimming behavior and brain 5-HT metabolism between low and high aggressive mice. Psychopharmacology (Berl.) 178 151-160.

Veenema, A. H., Meijer, O. C., de Kloet, E. R., Koolhaas, J. M., and Bohus, B. G. (2003a). Genetic selection for coping style predicts stressor susceptibility. J. Neuroendocrinol. 15, 256-267.

Veenema, A. H., Meijer, O. C., de Kloet, E. R., Koolhaas, J. M., and Bohus, B. G. (2003b). Differences in basal and stress-induced HPA regulation of wild house mice selected for high and low aggression. Horm. Behav. 43 , 197-204.

Vekovischeva, O. Y., Verbitskaya, E. V. Aitta-aho, T., Sandnabba, K., and Korpi, E. R. (2007). Multimetric statistical analysis of behavior in mice selected for high and low levels of isolation-induced male aggression. Behav. Processes 75, 23-32.

Vergnes, M., Depaulis, A., and Boehrer, A. (1988). Selective increase of offensive behavior in the rat following intrahypothalamic 5,7-DHT-induced serotonin depletion. Behav. Brain Res. 29, 85-91.

Virkkunen, M. (1985). Urinary free cortisol secretion in habitually violent offenders. Acta. Psychiatr. Scand. 72, 40-44.

Wasman, M., and Flynn, J. P. (1962). Directed attack elicited from hypothalamus. Arch. Neurol. 6, 220-227.

Woodworth, C. H. (1971). Attack elicited in rats by electrical stimulation of the lateral hypothalamus. Physiol. Behav. 6, 345-353.

WorldHealthOrganization(WHO).(2004). Fact sheet $\mathrm{N}^{\circ} 310$. http://www.who. int/mediacentre/factsheets/fs310/en/

Wrangham, R. W., Wilson, M. L., and Muller, M. N. (2006). Comparative rates of violence in chimpanzees and humans. Primates 47, 14-26.

Yao, R., Rameshwar, P., Donnelly, R. J., and Siegel, A. (1999). Neurokinin-1 expression and co-localization with glutamate and GABA in the hypothalamus of the cat. Mol. Brain Res. 71 149-58.

Yerkes, R. M. (1913). The heredity of savageness and wildness in rats. J. Anim. Behav. 7, 11-28.

Zuckerman, S. (1932). The Social Life of Monkeys and Apes. London: Routledge and Kegan Paul, Ltd.

Conflict of Interest Statement: The authors declare that the research was conducted in the absence of any commercial or financial relationships that could be construed as a potential conflict of interest.

Received: 30 July 2009; paper pending published: 11 September 2009; accepted: 19 February 2010; published online: 05 April 2010.

Citation: Natarajan D and Caramaschi D (2010) Animal violence demystified. Front. Behav. Neurosci. 4:9. doi: 10.3389/fnbeh.2010.00009

Copyright (C) 2010 Natarajan and Caramaschi. This is an open-access article subject to an exclusive license agreement between the authors and the Frontiers Research Foundation, which permits unrestricted use, distribution, and reproduction in any medium, provided the original authors and source are credited. 